\title{
An important fingerprint of wildfires on the European aerosol load
}

\author{
F. Barnaba ${ }^{1}$, F. Angelini ${ }^{1}$, G. Curci ${ }^{2}$, and G. P. Gobbi ${ }^{1}$ \\ ${ }^{1}$ Istituto di Scienze dell'Atmosfera e del Clima, Consiglio Nazionale delle Ricerche (ISAC-CNR), Roma, Italy \\ ${ }^{2}$ CETEMPS-Dipartimento di Fisica, Università degli Studi dell' Aquila, L'Aquila, Italy
}

Received: 7 December 2010 - Published in Atmos. Chem. Phys. Discuss.: 21 January 2011

Revised: 16 September 2011 - Accepted: 8 October 2011 - Published: 24 October 2011

\begin{abstract}
Wildland fires represent the major source of fine aerosols, i.e., atmospheric particles with diameters $<1 \mu \mathrm{m}$. The largest numbers of these fires occur in Africa, Asia and South America, but a not negligible fraction also occurs in Eastern Europe and former USSR countries, particularly in the Russian Federation, Ukraine and Kazakhstan. Besides the impact of large forest fires, recent studies also highlighted the crucial role played by routine agricultural fires in Eastern Europe and Russia on the Arctic atmosphere. An evaluation of the impact of these fires over Europe is currently not available. The assessment of the relative contribution of fires to the European aerosol burden is hampered by the complex mixing of natural and anthropogenic particle types across the continent. In this study we use long term (20022007) satellite-based fires and aerosol data coupled to atmospheric trajectory modelling in the attempt to estimate the wildfires contribution to the European aerosol optical thickness (AOT). Based on this dataset, we provide evidence that fires-related aerosols play a major role in shaping the AOT yearly cycle at the continental scale. In general, the regions most impacted by wildfires emissions and/or transport are Eastern and Central Europe as well as Scandinavia. Conversely, a minor impact is found in Western Europe and in the Western Mediterranean. We estimate that in spring 5 to $35 \%$ of the European fine fraction AOT (FFAOT) is attributable to wildland fires. The estimated impact maximizes in April (20-35\%) in Eastern and Central Europe as well as in Scandinavia and in the Central Mediterranean. An important contribution of wildfires to the FFAOT is also found in summer over most of the continent, particularly in August over Eastern Europe (28\%) and the Mediterranean regions, from Turkey (34\%) to the Western Mediterranean (25\%). Although preliminary, our results suggest that this fires-related,
\end{abstract}

Correspondence to: F. Barnaba (f.barnaba@isac.cnr.it) continent-wide haze plays a not negligible role on the $\mathrm{Eu}-$ ropean radiation budget, and possibly, on the European air quality, therefore representing a clear target for mitigation.

\section{Introduction}

The uncontrolled use of fire for clearing forest and woodland for agriculture is estimated to account for up to $90 \%$ of world's wildland fires (FAO, 2009). The majority of the wildland fires in the European area occurs in the croplanddominated regions of Eastern Europe and European Russia, with a major role played by former USSR countries as Ukraine, Kazakhstan and the Russian Federation. In these regions, a remarkable $50-70 \%$ of all fires detected from satellite in 2001-2003 were cropland burning (Koronzti et al., 2006). In the Russian Federation, about $90 \%$ of fires in the period 2002-2005 were ignited by people (Mollicone et al., 2006).

In terms of emissions, biomass burning during wildland fires is an important source of trace gases and one of the largest global contributors to accumulation mode aerosols, i.e., atmospheric particles with diameters $<1 \mu \mathrm{m}$ (e.g., Kasischke and Penner, 2004; Reid et al., 2005a). These emissions can be transported over long distances, leading to regionally elevated aerosol loadings (e.g., Damoah et al., 2004; McMeeking et al., 2006; Hodzic et al., 2007).

The major role agricultural fires in Eastern Europe and Russia play in the composition of the Arctic atmosphere has been recently highlighted (e.g., Generoso et al 2007; Stohl 2007; Warneke et al., 2010). Several studies also investigated properties and impacts of biomass burning events on aerosol properties at different European sites/regions (e.g., Formenti et al., 2002; Balis et al., 2003; Pace et al., 2005; Müller et al., 2005; Niemi et al., 2005; Arola et al., 2007; Witham and Manning, 2007; Hodzic et al., 2007; Sciare et al., 2008; Amiridis et al., 2009; Saarnio et al., 2010; Alves

Published by Copernicus Publications on behalf of the European Geosciences Union. 
et al., 2011). However, being fragmented both in space and time, this broad literature does not allow to draw a more general picture of the impact of fires on the aerosol loads at the continental scale. Still, meteorological fields over the continent are often favourable to easterly transport, typically in spring (e.g., Chubarova, 2009), when agricultural fire activity is maximum. Current capability of global or regional chemistry-transport models to include accurately quantified fires emissions and reproduce some relevant aerosol properties is also affected by large uncertainties (e.g., Kasischke and Penner, 2004; Wiedinmyer et al., 2006; Langmann et al., 2009; Menut and Bessagner, 2010). Thus a reliable modelbased assessment of the impact of fires on the European aerosol load is also lacking.

In this study we aim at investigating the impact of wildfires on the European "aerosol optical thickness" (AOT), this being the aerosol optical parameter at the basis of aerosol radiative forcing computations, i.e., at the basis of aerosol climatic impact evaluations (e.g., Tegen et al., 2000; Marmer et al., 2007). The term wildland fires is employed here to denote open fires of various vegetation (e.g., forests, grasslands, agricultural residues) and peat that are set by humans or occur naturally (e.g., by lightening), the latter representing an almost negligible portion of the total.

Over Europe and the Mediterranean, the AOT is typically built up by a complex mixture of different components of both natural and anthropogenic origin. Marine particles from the surroundings seas and desert dust advected from the nearby Sahara desert mix, in variable proportions, with local and/or long-range transported pollution produced by human activities (e.g., Barnaba and Gobbi, 2004). In this region, the AOT yearly cycle typically shows a winter minimum and a spring/summer maximum (e.g., Yu et al., 2003; Edwards et al., 2004; Papadimas et al., 2008, Chubarova, 2009), with some inter-annual and spatial variability. This annual AOT behaviour is mainly driven by in-phase annual cycles of major aerosol-source factors (e.g., radiation, which favours secondary aerosol formation, and convection, which facilitates particles and gases injection and mixing into the atmosphere), and opposite cycles of major aerosol removal agents as wind speed and precipitation (e.g., Koelemeijer et al., 2006; Mehta and Yang, 2008; Papadimas et al., 2008; Chubarova, 2009). Deviations from a "regular", sinusoidallike AOT cycle have been however observed in Europe. Some of these deviations are attributable to the transport of Saharan dust, an important season dependent phenomenon which typically maximizes in spring/summer and minimizes in winter (e.g., Moulin et al., 1998; Barnaba and Gobbi, 2004; Papayannis et al., 2008). However, other, systematic seasonal increases of AOT in spring and summer have been observed which cannot be attributed, or uniquely attributed, to Saharan dust transport, since mainly associated to fine particulate matter (e.g., Aculinin et al., 2004; Chubarova 2009; Sicard et al., 2011). Vegetation fires in Eastern Europe or in the Mediterranean countries have been shown to enhance the local aerosol load, particularly in the hottest periods/countries, when relatively small-scale, human-initiated fires often develop into uncontrolled widespread fires (e.g, Hodzic et al., 2007; Sciare et al., 2008; Amiridis et al., 2009).

Here we use long term (2002-2007) satellite aerosol and fires observations coupled to atmospheric transport modelling (Sect. 2) and set up a methodology to derive monthlyresolved quantitative estimates of the wildfires contribution to the fine fraction AOT in Europe (Sect. 3). Our results provide evidences that, over the whole continent, wildfires play a major role in modulating the AOT yearly cycle, in particular its fine mode fraction.

\section{Methods}

This study focuses on the 6-year period 2002-2007 and employs (1) AOT data from the MISR sensor on board the NASA-Terra platform (e.g., Martonchik et al., 2009; Kahn et al., 2010), (2) fires data (both Fire Counts, FC, and Fire Radiative Power, FRP, data) from the MODIS sensor on board the same NASA-Terra platform (e.g., Giglio et al., 2003, 2006), (3) forward trajectories computed by means of the NOAA-HYSPLIT Lagrangian integrated trajectory model (Draxler and Hess, 1998).

To investigate the aerosol variability during the year, monthly statistics of significant parameters were considered and further averaged over seven selected European target regions covering most of the continent. These regions are (Fig. 1): Scandinavia $\left(5^{\circ}\right.$ to $28^{\circ} \mathrm{E}$; $56^{\circ}$ to $64^{\circ} \mathrm{N}$, cyan shaded area), Western Europe $\left(-11^{\circ}\right.$ to $-7^{\circ} \mathrm{E} ; 46^{\circ}$ to $56^{\circ} \mathrm{N}$, magenta shaded area), Central Europe ( $7^{\circ}$ to $25^{\circ} \mathrm{E} ; 46^{\circ}$ to $56^{\circ} \mathrm{N}$, green shaded area), Eastern Europe $\left(25^{\circ}\right.$ to $42^{\circ} \mathrm{E}$; $46^{\circ}$ to $56^{\circ} \mathrm{N}$, reddish shaded area), Western Mediterranean $\left(-11^{\circ}\right.$ to $-7^{\circ} \mathrm{E} ; 36^{\circ}$ to $46^{\circ} \mathrm{N}$, orange shaded area), Central Mediterranean $\left(7^{\circ}\right.$ to $25^{\circ} \mathrm{E}, 36^{\circ}$ to $46^{\circ} \mathrm{N}$, bluish shaded area) and Turkey $\left(25^{\circ}\right.$ to $42^{\circ} \mathrm{E} ; 36^{\circ}$ to $46^{\circ} \mathrm{N}$, gray shaded area). Details on the datasets and data processing are described hereafter.

\subsection{MISR AOT data}

The MISR instrument (Diner et al., 1998) infers AOT by using observations of nine cameras pointing at different angles and separates aerosol from land scattering based on the angular distribution of the up-welling radiance phase function. Details on the MISR aerosol retrieval can be found in Martonchik et al. (2009). The quality of the MISR aerosol products has been carefully evaluated by Kahn et al. (2010) through the comparison with relevant aerosol data from the worldwide AERONET sunphotometer network (Holben et al., 1998). That study shows good quality of the MISR AOT retrievals, with about three-fourth of MISR measurements within $\pm 20 \%$ of corresponding AERONET measurements, and about half within $\pm 10 \%$. Focusing specifically on the 


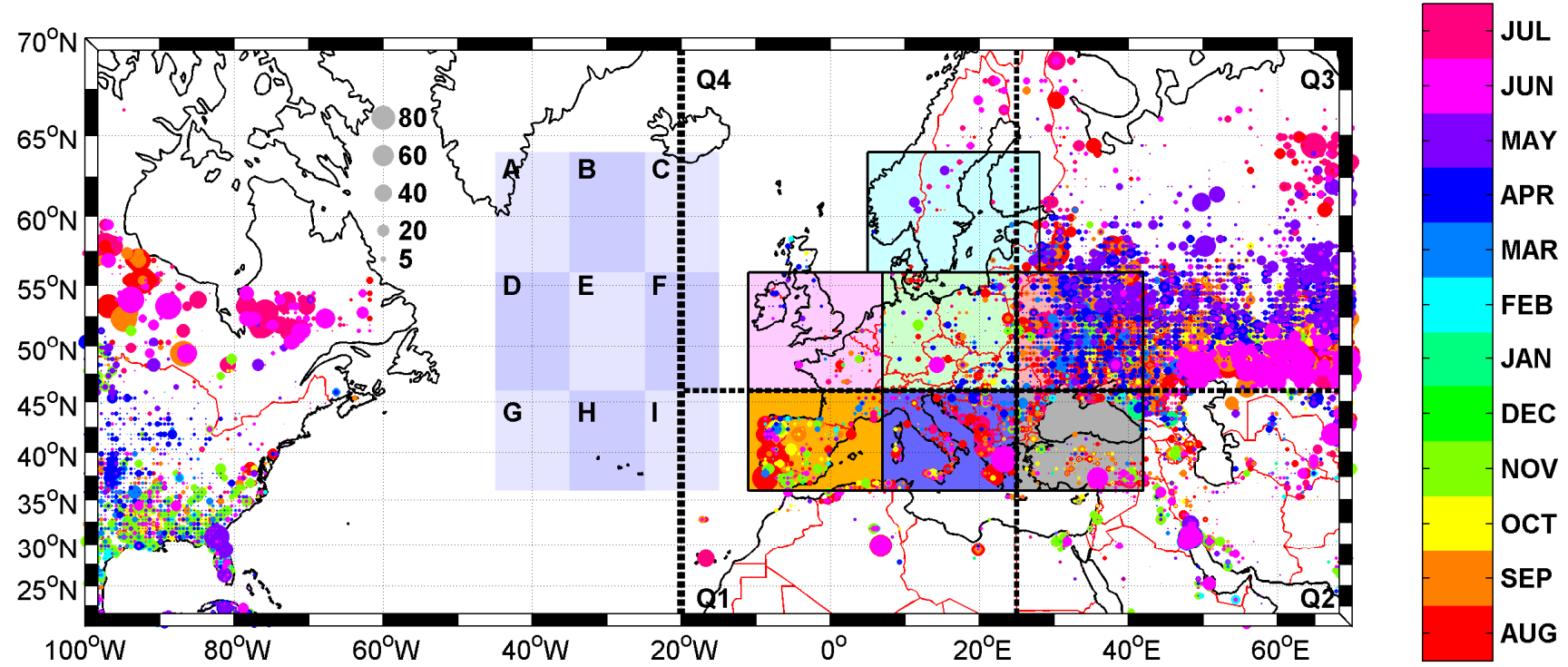

Fig. 1. Monthly mean Fire Counts (FC) from MODIS Terra data in the period 2002-2007 (circles). The size and colour of the circles refer, respectively, to the fire count value (FC/1000 $\mathrm{km}^{2} \mathrm{day}^{-1}$ ) and month of the year (see relevant legends). The map also shows: (i) the seven target regions addressed in this study and namely Scandinavia (cyan), Western Europe (magenta), Central Europe (green), Eastern Europe (red), Western Mediterranean (orange), Central Mediterranean (blue) and Turkey (gray); (ii) the whole region considered for the FWTD computations $\left(20^{\circ} \mathrm{W}-70^{\circ} \mathrm{E} ; 20^{\circ} \mathrm{N}-70^{\circ} \mathrm{N}\right.$, delimited by the thick dotted line) and its division into four quadrants Q1-to-Q4 (thin dashed line-delimited areas); (iii) the seven Atlantic control regions considered in the study (violet areas, labelled A to I).

"biomass burning" category, the MISR mean AOT is well within the limits given above. Scenes with a large fraction of dust or smoke, generally display a poorer agreement.

In this study we employ monthly mean Level $3,0.5^{\circ} \times 0.5^{\circ}$ resolution MISR aerosol data (MIL3MAE dataset). We use the latest released (version 31) AOT dataset (at $555 \mathrm{~nm}$ ) and the relevant AOT due to the aerosol finest fraction (i.e., AOT due to particles having effective radius smaller than $0.35 \mu \mathrm{m}$, hereafter referred to as FFAOT). The AOT dataset is a MISR Validated Stage 3 product (i.e., uncertainties are estimated from independent measurements representing global conditions) whereas the MISR particle size fractional AOT amounts are Validated Stage 2 products (i.e., uncertainties are estimated from more widely distributed independent measurements).

\subsection{MODIS fires data}

We use monthly mean fires counts (FC, counts $/ \mathrm{m}^{2} \mathrm{day}^{-1}$ ) and fire radiative power (FRP, MW or $\mathrm{Mjs}^{-1}$ ) data from MODIS-Terra. The fire detection by satellite is performed exploiting their strong emissions of mid-infrared radiation. MODIS fires retrieval uses a contextual algorithm based on the brightness temperature derived from the $4 \mu \mathrm{m}$ and $11 \mu \mathrm{m}$ channels (Giglio et al., 2003). Detailed information about the MODIS fire products can be found in Justice et al. (2006).

The FC dataset used in this study is the MODIS-Terra overpass corrected fire pixel count product available through the NASA Earth Observation (NEO) portal (http://neo.sci. gsfc.nasa.gov). It is a gridded statistical summary of fire pixel information intended for use in regional and global modelling with a spatial resolution of $0.5^{\circ}$ for time periods of one calendar month (Justice et al., 2006). To provide a view of the typical spatial-temporal variability of fire counts in Europe, the monthly mean number of fires computed over the whole period addressed here (2002-2007) is shown as coloured circles in Fig. 1.

Fires release heat energy which propagates in space and facilitates fire detection by remote sensing. Satellite observations actually measure the rate at which energy is emitted by a fire during the combustion, i.e., the Fire Radiative Power, FRP (e.g., Kaufman et al., 1998; Giglio et al., 2003; Wooster et al., 2005). This can serve as an indicator of the rate at which aerosols (and gases) are released (e.g., Kaufmann et al., 1998). FRP estimated accuracy from MODIS is of about $15 \%$ (Wooster et al., 2005). In this study we use MODIS-Terra monthly FRP data at $1^{\circ}$ resolution (MODIS Active Fire Product MOD14CM1, version V005) available through the Giovanni web-based application (http: //disc.sci.gsfc.nasa.gov/giovanni), developed by the NASA Goddard Earth Sciences Data and Information Services Center (GES DISC) (Acker and Leptoukh, 2007). 


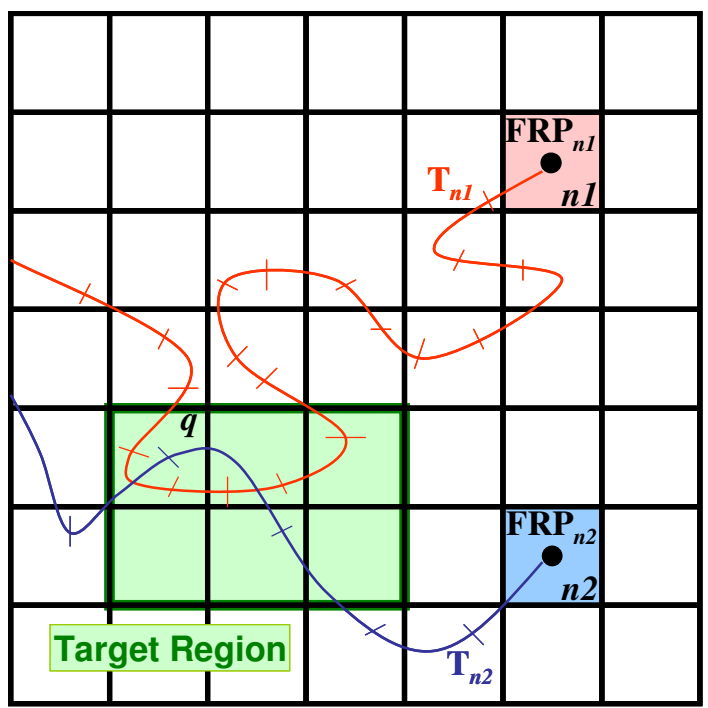

Fig. 2. Schematic of the procedure used to build the FWTD quantity $\left(2.5^{\circ}\right.$-resolution) used in this study (see Sect. 2.3.1 for details). The subscript $n$ identifies the starting cell (associated to a fire count value, $\mathrm{FC}>25$ fire counts $/ 1000 \mathrm{~km}^{2} \mathrm{day}^{-1}$ and to a fire radiative power value $\left.\mathrm{FRP}_{n}\right) ; q$ is the target cell. A single, 10-day forward trajectory $T_{n}$ starts from the centre of cell $n$ in each day of the month at 10:30 LT. Trajectories are sampled hourly (here represented as trajectory segments). Each target cell $q$ receives contributions from each starting cell $n$, leading to build up the monthly resolved FWTD field (e.g. Fig. 3). FWTD averages over a given Target Region (here represented by the green area) are also obtained from this fields (e.g. Fig. 4).

\subsection{Forward trajectory computations}

We use the NOAA-HYSPLIT Lagrangian integrated trajectory model (http://ready.arl.noaa.gov) to compute 10-day forward trajectories originating from fires detected in the whole domain addressed (from $20^{\circ} \mathrm{W}$ to $70^{\circ} \mathrm{E}$ and from $20^{\circ}$ to $70^{\circ} \mathrm{N}$, dashed line-delimited area in Fig. 1). Trajectories are driven by the $1^{\circ}$-resolution NCEP analyses. We divide the domain in a regular $2.5^{\circ}$-resolution grid and start trajectories from those grid-cell centres where and when fires are detected. This resolution is chosen as a compromise between good spatial resolution of sources and acceptable computing time. A minimum fire count threshold of 25 fire counts $/ 1000 \mathrm{~km}^{2} \mathrm{day}^{-1}$ was set to start a trajectory computation (which corresponds to an average of 1 fire count $/ 1000 \mathrm{~km}^{2} \mathrm{day}^{-1}$ in the $25,0.5^{\circ}$ by $0.5^{\circ}$ cells that compose the $2.5^{\circ}$ by $2.5^{\circ}$ grid box). One trajectory per day was computed for the whole 2002-2007 period, starting at 10:30 LT (i.e., close to the Terra overpass time).

The starting altitude of trajectories was set at $500 \mathrm{~m}$ a.g.l. Some sensitivity tests were performed by (1) changing the trajectories starting altitude within the first $1000 \mathrm{~m}$ and (2) eliminating those trajectories for which the starting altitude
$(500 \mathrm{~m})$ was above the model estimated "atmospheric mixing layer" in the starting cell. Both tests showed minor $(<10 \%)$ changes in the results. Furthermore, the "mixing layer" control reduced the trajectories dataset by about $10 \%$ in summer and up to $40 \%$ in winter. Therefore these options were not used in getting the results presented here.

Overall, a total of about 360000 forward trajectories is included in this study.

\subsubsection{Coupling fires data and forward trajectory computations}

With the aim of evaluating the contribution of fires to the AOT, a specific quantity has been defined and used as a proxy for the coupling of fire emissions with atmospheric dispersion capabilities. This quantity, in the following referred to as Fire Weighted Trajectory Density (FWTD), has been derived following the methodology detailed below and illustrated in Fig. 2. To match the horizontal resolution of the forward trajectory computations, we first re-mapped the monthly fields of both the Fire Radiative Power and Fire Counts on a $2.5^{\circ}$ by $2.5^{\circ}$ grid. Each cell $n$ of the European domain considered (area delimited by the dashed line in Fig. 1) is thus associated to a monthly mean FRP (and FC) value, FRP $n$ (and FCn). For each day of the month (starting month, sm), a 10-day forward trajectory $T_{n}$ originating at the centre of cell $n$ is computed and sampled at an hourly rate (provided that $\mathrm{FC} n>25$ fire count $/ 1000 \mathrm{~km}^{2} /$ day). For a given cell $q$ along the $T_{n}$ path, we compute the contribution of $T_{n}$ to $q$ as:

$\operatorname{FWTD}(\mathrm{am}$, day $, n, q)=\mathrm{FRP}_{n}(\mathrm{sm}) \sum_{t_{h}} \exp \left(-t_{h} / \tau\right)$

where am is the arrival month (which, depending on the starting day, may or not coincide with the starting month, sm), $t_{h}$ is the time of travel (in hours) from the starting cell $n$ to cell $q$. The sum over $t_{h}$ accounts for the fact that a single $T_{n}$ can spend more time steps over cell $q$. The exponential decay is used to take into account the typical lifetime of aerosol in the troposphere (e.g., Rangarajan, 1992; Ahmed et al., 2004; Papastefanou, 2006). In particular, a time constant $\tau=5$ days (i.e., $120 \mathrm{~h}$ ) has been set which also allows to avoid sharp transitions at the end of the 10-day forward trajectories (after 10 days of travel the $\mathrm{FRP}_{n}$ corrected for the exponential decay is about $10 \%$ of the original value). Note that this exponential decay also reduces the impact on the FWTD quantity of the total error expected on each single trajectory, which is estimated to be $15-30 \%$ of the travel distance.

Integrating the contribution to cell $q$ of each cell $n$ (and thus trajectory $T_{n}$ ) of the domain, we get:

$\operatorname{FWTD}(\operatorname{am}$, day,$q)=\sum_{n=1}^{N} \operatorname{FRP}_{n}(\mathrm{sm}) \sum_{t_{h}} \exp \left(-t_{h} / \tau\right)$ 

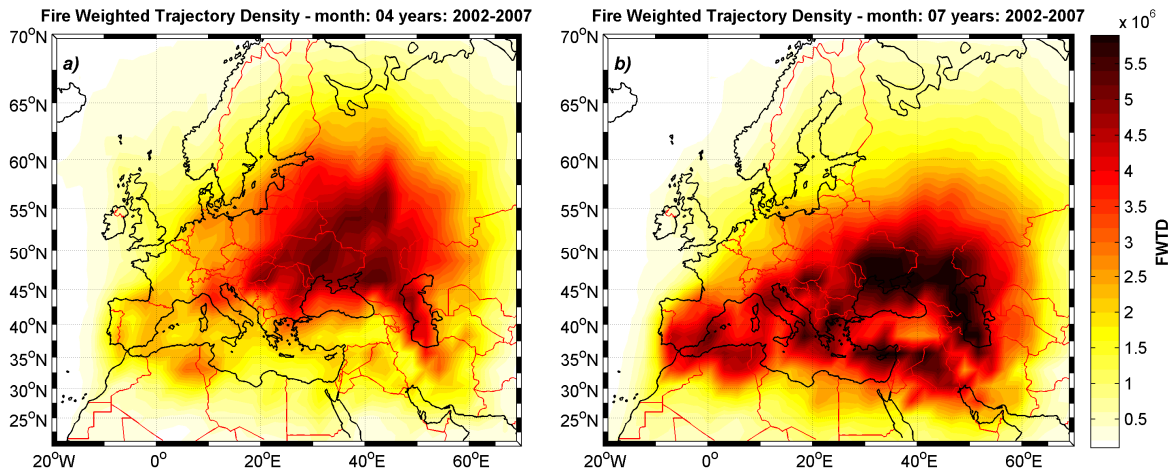

Fig. 3. FWTD fields obtained for the months of April (a) and July (b) as average over the 2002-2007 period.

Considering all the days in the month we obtain, for each cell $q$ :

$\operatorname{FWTD}(\operatorname{am}, q)=\sum_{\text {day }=1}^{D} \sum_{n=1}^{N} \operatorname{FRP}_{n}(\operatorname{sm}) \sum_{t_{h}} \exp \left(-t_{h} / \tau\right)$

Examples of the so derived FWTD field over Europe for the months of April and July (average over the period 20022007) are shown in Fig. 3a and b, respectively (the complete set of the 12 months FWTD-field is given in a Supplement Fig. S1). Figure 3a clearly shows the April fires (mostly detected over Eastern Europe/Ukraine as shown in Fig. 1) to impact the whole continent, and particularly the North Eastern sector. In July (Fig. 3b), the additional contribution of fires from the Mediterranean countries (Spain, Italy, Greece) and the North African regions is also well visible and keeps significant until September (Fig. S1).

The FWTD $(\mathrm{am}, q)$ field has then been integrated over the seven selected European target regions (TR), obtaining monthly and regionally resolved values:

$\mathrm{FWTD}=\sum_{q \in T R} \sum_{\text {day }=1}^{D} \sum_{n=1}^{N} \mathrm{FRP}_{n}(\mathrm{sm}) \sum_{t_{h}} \exp \left(-t_{h} / \tau\right)$

(the dependence of FWTD on the month, am, and target region has been omitted for brevity, as will be done in the following). The resulting monthly and regionally resolved quantities will be presented and discussed in the next sections.

\section{Results}

For each year of the 2002-2007 period, the monthly AOT and FFAOT datasets were both averaged regionally over the seven addressed European regions of Fig. 1. In Fig. 4 we show the monthly mean AOT and FFAOT (squares and triangles, respectively) for the whole period 2002-2007 for each target region (panels a to g). The figure confirms the expected maximum aerosol load in spring/summer and minimum in winter. It further shows that in most of the addressed regions the AOT follows a clear bimodal yearly cycle, with maxima in April and July-August. This bimodality, particularly marked in the Central and Eastern European regions and less detectable in the Western ones, is also evident in the fine fraction AOT. Conversely, we could not find a similar seasonality in any of the meteorological parameters investigated ( $P, T$, Radiation, Precipitable Water, Precipitation).

FFAOT over Europe is found to account for approximately $35 \%$ to $70 \%$ of the total AOT, with the maximum values and relative contributions in Eastern Europe and minima in Turkey and Western Mediterranean.

The inter-annual variability associated to both the AOT and FFAOT monthly means can be evaluated through the relevant standard deviations shown in Fig. 4 (shaded areas indicate \pm 1 standard deviation). This variability is likely related to the irregular nature of fires. In fact, standard deviations show two minima, the first in the winter months and the second at mid-year (typically in May-June), in correspondence to the AOT minimum. In these months, such a reduced AOT variability over the period 2002-2007 indicates rather similar aerosol loads year by year. Conversely, the standard deviation increase in correspondence with the two maxima further indicates these to be associated to phenomena having a non negligible inter-annual variability. On the other hand this variability cannot be attributed, or are least cannot be uniquely attributed, to desert dust advection as 1) it shows the same yearly pattern in both AOT and FFAOT and 2) desert dust advection towards Europe and the Mediterranean is maximum in spring and summer (e.g., Moulin et al., 1998; Barnaba and Gobbi, 2004), a pattern that would not agree with the observed AOT decrease in June.

The regional, monthly-averaged Fire Weighted Trajectory Density (FWTD) values obtained as described in Sect. 2.3 are shown in Fig. 4 (gray diamonds, right axis) for direct comparison with the AOT cycles. We find a clear bimodality in the FWTDs, with a timing very similar to that of AOT and FFAOT, particularly evident in the Central and Eastern Europe regions. Also note that, as for the AOT cases, the variability associated to the FWTD minimizes in winter and 

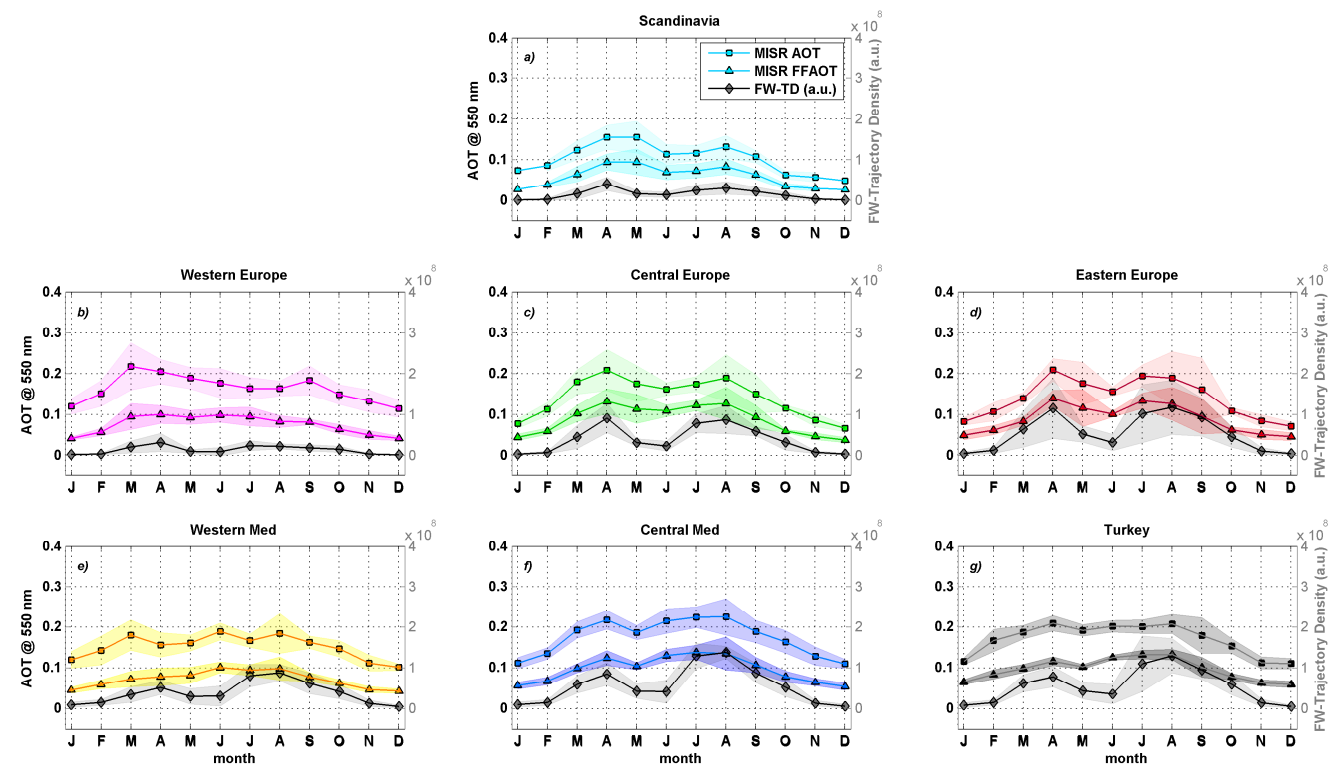

Fig. 4. Monthly mean AOT (squares) and FFAOT (triangles) derived from MISR data in the period 2002-2007 in the seven target regions addressed in this study (panels a to g), and corresponding FWTD values (diamonds, right axis) computed coupling MODIS fires data with forward trajectories computations (see Sect. 2.3.1 for details). For each variable, shaded areas indicate \pm 1 standard deviation.
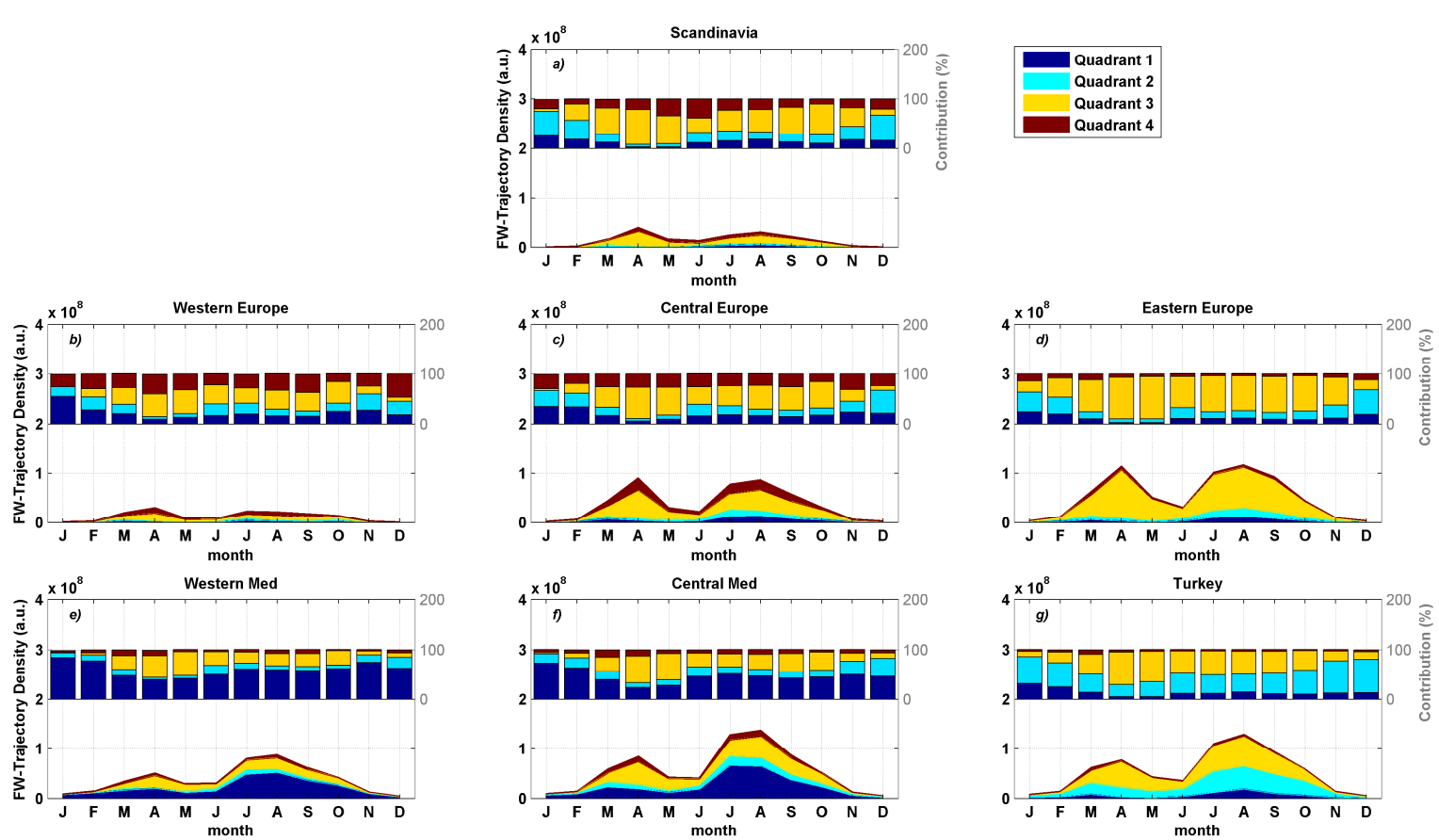

Fig. 5. Absolute (left axis) and percent (histograms, right axis) contribution of the four quadrants Q1, Q2, Q3, Q4 (Fig. 1) to the FWTD values derived for the seven target regions addressed in this study.

in the mid-year minimum (May-June) between the two maxima. The FWTD seasonality is mainly driven by the characteristic bimodality of the agricultural fire activity in Europe, with two maxima in spring and summer correspond- ing respectively to the planting and harvesting periods (Korontzi et al., 2006). In summer, an additional contribution from natural and/or human initiated fires invigorated by dryness and hot temperatures is also expected to contribute to 
the FWTD values observed, especially in the southernmost European regions.

Overall, a good correlation $(R \geq 0.8$, Table 1$)$ between FFAOT and FWTD values is found in each region but Western Mediterranean, confirming the hypothesis that a strong link exists between the fire source and the observed fine aerosol optical thickness.

To investigate the role of Mediterranean and Eastern Europe fires in generating the patterns shown in Fig. 4, we further divided the whole origin region considered for the FWTD computations (dashed area in Fig. 1) into four quadrants (Q1, Q2, Q3, Q4 in Fig. 1). The absolute and relative contributions from these quadrants to the total FWTD values are shown in Fig. 5 (area graphs and histograms, respectively). Figure 5 shows fires in the southwest quadrant Q1 (which includes the southern European states of Portugal, Spain, Italy, Greece, Slovenia and the others former Yugoslavia countries as well as Northern Africa) to have an important impact on the total FWTD only in two of the seven target European regions considered, namely Western Med and Central Med. In fact, in these two regions Q1 fires account for more than 45-50\% of the FWTD during all winter, summer and autumn months. Only in the spring period this contribution decreases to about $40 \%$ and $25 \%$ in the Western and Central Mediterranean, respectively, due to the increasing relative weight of Q3 fires. In the other target regions, the portion of FWTD due to fires originating in Q1 maximizes in summer, but its relative contribution keeps lower than $20 \%$. Conversely, fires originating in the NE European quadrant Q3 (which includes Ukraine, Moldova, Belarus, Russia, Kazakhstan) are found to impact the whole continent during most of the year, and particularly in spring (see also Fig. 3a). In April, the minimum contribution of Q3 fires to the total FWTD is about $45 \%$ (in Western Europe and Western Med) while high contributions are obtained for Central Med and Central Europe (about 60\%), Turkey and Scandinavia (about $70 \%$ ) and Eastern Europe (85\%). A minor role is played by Q2 and Q4 fires, whose effects are found to be mostly local (see for example the Q2 fires impact on the Turkey FWTD values, Fig. 5g).

This analysis suggests a larger impact of springtime agricultural fires on the continental AOT with respect to the summer ones, which are mostly associated to the burning of other type of vegetation (e.g., forests). The more marked fingerprint of agricultural fires in spring with respect to summer was also reported by Sciare et al. (2008) based on long term in situ aerosol measurements performed in Creete (Greece). In particular, rather low OC/EC ratios were observed in spring compared to summer which are more compatible with agricultural waste burning (e.g., Andreae and Merlet, 2001; Hays et al., 2005). The reason for higher enhancement ratios of elemental carbon in the agricultural fire plumes with respect to forest fire plumes reflects the fact that agricultural fires burn at lower temperatures and tend to smoulder, emitting higher concentrations of products from incomplete car-
Table 1. Correlation coefficient $(R)$ between FFAOT and FWTD values for the seven regions addressed in this study and Correction Factors (CF) derived following Eq. (7) and used to convert FWTD values into FFAOT values (Eq. 6).

\begin{tabular}{lcr}
\hline Target Region & $R$ & $\mathrm{CF}\left(\times 1^{10}\right)$ \\
\hline Western Med (WMed) & 0.80 & $2.6 \pm 1.7$ \\
Central Med (CMed) & 0.88 & $2.7 \pm 1.3$ \\
Turkey (TUR) & 0.90 & $3.2 \pm 1.7$ \\
Western Europe (WEU) & 0.47 & $3.1 \pm 5.5$ \\
Central Europe (CEU) & 0.91 & $3.4 \pm 1.7$ \\
Eastern Europe (EEU) & 0.93 & $2.7 \pm 1.4$ \\
Scandinavia (SCA) & 0.81 & $7.4 \pm 5.9$ \\
\hline
\end{tabular}

bon combustion. From an optical point of view, enrichment in elemental carbon translates into enhanced aerosol absorption, thus enhanced aerosol extinction and AOT.

\subsection{Estimating wildfires contribution to the fine fraction AOT}

In this study we assume that the impact of wildfires on the optical aerosol load is limited to the fine fraction AOT (FFAOT). In fact, being mainly the result of condensation/coalescence processes, biomass burning particles are predominantly found in this size range (e.g., Reid, 2005a; Janhäll et al., 2010). This assumption also allows minimizing in our analysis possible "disturbances" by mineral dust, pollen or marine aerosol particles contributions to the AOT, mainly expected to occur in the coarse aerosol fraction (e.g., d'Almeida et al., 1991).

Two approaches have been used to estimate the mean contribution of wildfires to the European FFAOT. The first one is based on the measurement-derived FFAOT data, while the second one also includes of the FWTD computations formulated here (see Sect. 2.3). In the first case (indicated by the subscript 1) we assume the monthly mean FFAOT values in each region to be the result of the contribution of a "regional background" (FFAOT $\mathrm{RB}$ ) plus that of wildfires (FFAOT $\mathrm{WF}_{\text {), }}$ i.e., for each month, $m_{i}$, it is:

$$
\operatorname{FFAOT}\left(m_{i}\right)=\operatorname{FFAOT}_{\mathrm{RB}}\left(m_{i}\right)+\operatorname{FFAOT}_{\mathrm{WF}, 1}\left(m_{i}\right)
$$

We then assume the regional background FFAOT to follow a sinusoidal behaviour during the year, as supported by climatological evidences in mostly unperturbed regions (e.g., Yu et al., 2003).

For each region, the FFAOT $_{\mathrm{RB}}$ is thus obtained fitting with a sine function the measurement-based FFAOT values of all those months in which, based on the FWTD computations, the expected wildfires contribution is negligible (January, February, November, December) or minimum (May or June, depending on the region). The FFAOT RB $_{\text {curves ob- }}$ tained are shown in Fig. 6 (thin black lines) together with the 

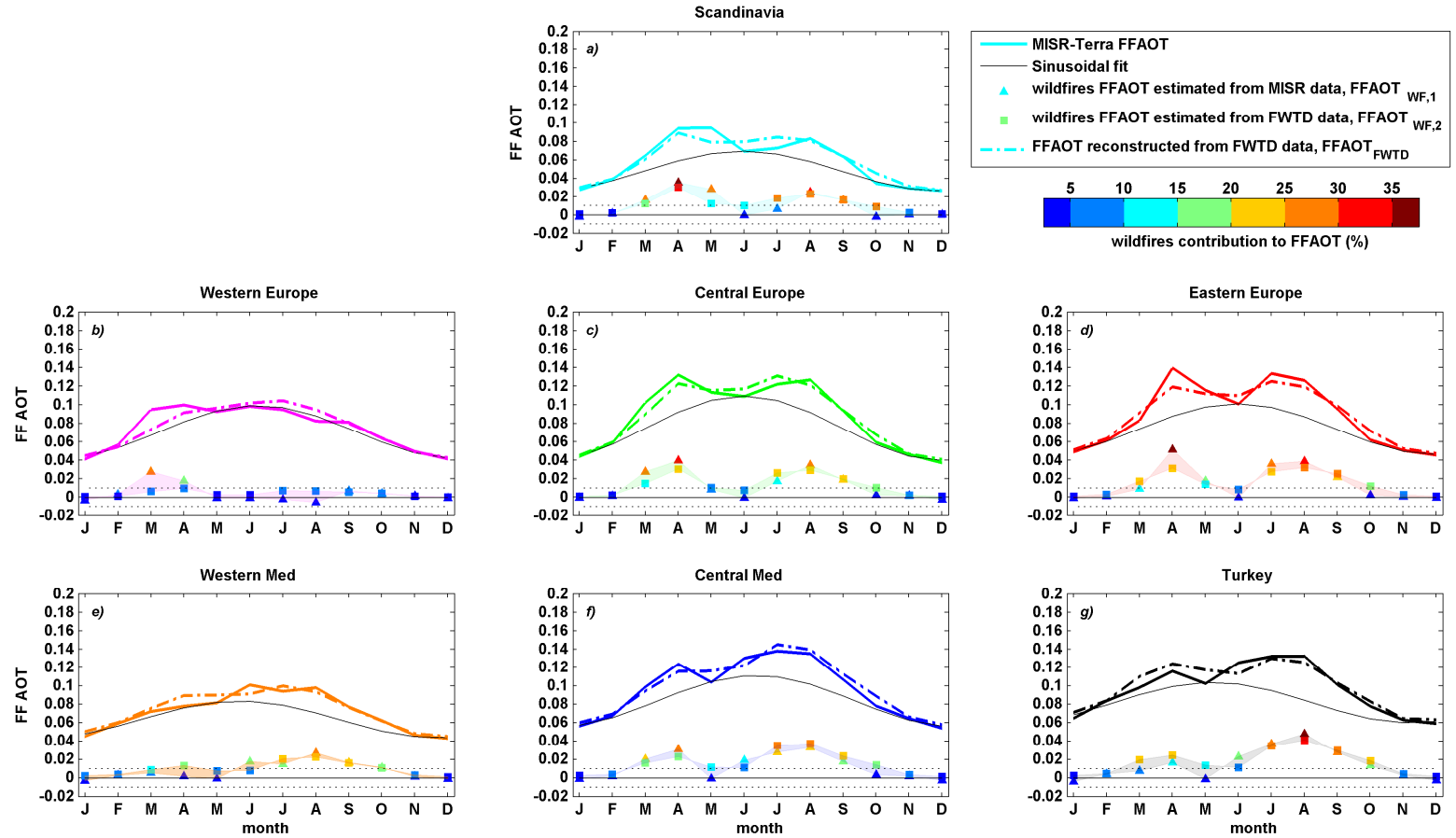

Fig. 6. Each panel (a to g, referring to one of the seven target regions addressed in this study) shows: (i) the monthly mean FFAOT as measured by MISR (thick coloured line); (ii) the monthly mean wildfires contributions to the FFAOT as estimated from the MISR FFAOT data (FFAOT $\mathrm{WF}_{\mathrm{W}, 1}$, coloured triangles) and from the FWTD computations (FFAOT ${ }_{\mathrm{WF}, 2}$, coloured squares, the symbol colour indicating the relative percentage with respect to the total FFAOT, see colour bar); (iii) the sinusoidal fit, FFAOT $_{\mathrm{RB}}$, used to derive FFAOT $\mathrm{WF}, 1$ (thin black line); and (iv) the total FFAOT as reconstructed from FFAOT $\mathrm{WF}_{2}$ plus the sinusoidal fit, FFAOT $\mathrm{RB}$ (see Sect. 3.1 for details).

original MISR FFAOT dataset from which these were computed (continuous colour lines). As over Europe the 'regional background' also includes an important anthropogenic contribution, the FFAOT $\mathrm{RB}_{\mathrm{RB}}$ absolute values vary depending on the region, with lowest values observed in the Western sectors as well as in Scandinavia.

The derived FFAOT ${ }_{\mathrm{WF}, 1}$ values (Eq. 5) are shown as coloured triangles in Fig. 6, the colour indicating the relative (\%) contribution of FFAOT ${ }_{W F, 1}$ to the total FFAOT.

In the second case (indicated by subscript 2), we assume the FWTD obtained in each region to be proportional to the wildfires-related FFAOT, through a region-dependent conversion factor, $\mathrm{CF}$, i.e.:

$$
\text { FFAOT }_{\mathrm{WF}, 2}\left(m_{i}\right)=\mathrm{CF} \times \mathrm{FWTD}\left(m_{i}\right)
$$

The conversion factor is computed only considering those months, $m_{j}$, characterized by a not negligible wildfires contribution, i.e., those months not used to compute the sinusoidal fit describing FFAOT $_{\mathrm{RB}}$. In particular, for each region, it is:

$\mathrm{CF}=\operatorname{mean}\left[\left(\operatorname{FFAOT}\left(m_{j}\right)-\operatorname{FFAOT}_{\mathrm{RB}}\left(m_{j}\right)\right) / \operatorname{FWTD}\left(m_{j}\right)\right](7)$

The CF values obtained in the seven European target regions addressed are summarized in Table 1.
The derived FFAOT ${ }_{\mathrm{WF}, 2}$ values (Eq. 6) are shown as coloured squares in Fig. 6, the colour indicating the relative (\%) contribution of FFAOT ${ }_{\mathrm{WF}, 2}$ to the total FFAOT.

Finally, for direct comparison with the MISR measured one, the FWTD-based FFAOT is also reconstructed as:

$$
\operatorname{FFAOT}_{\mathrm{FWTD}}\left(m_{i}\right)=\operatorname{FFAOT}_{\mathrm{WF}, 2}\left(m_{i}\right)+\operatorname{FFAOT}_{\mathrm{RB}}\left(m_{i}\right)
$$

This is reported as dash-dotted lines in Fig. 6. Figure 6 shows the two estimates to follow very similar yearly patterns and to have rather close absolute values, except for a few cases (e.g. March values in Western Europe). We then use their average value, FFAOTWF_mean (Table 2), as a final indication of the estimated regional, monthly-average contribution of wildfires to the total FFAOT measured by MISR over Europe. This analysis indicates that, in spring and summer, 10 to $30 \%$ of the fine aerosol optical thickness in Europe is related to wildfires emissions (Table 2). In April the maximum impact of wildfires on the fine fraction AOT (relative weight of $20-35 \%$ ) is found in Central and Eastern Europe, in Scandinavia and in the Central Mediterranean, while in August the wildfires contribution to the FFAOT overcomes $25 \%$ in all the addressed regions but Western Europe. In general, the regions less affected by wildfires emissions and/or transport appear to be the western ones (Western Europe and Western 
Table 2. Monthly, regional values ( \pm 1 st. dev.) of the estimated wildfires contribution to the FFAOT, FFAOT WF_mean, and (in parenthesis) relative percentage to the total FFAOT.

\begin{tabular}{|c|c|c|c|c|c|c|c|c|c|c|c|c|}
\hline \multirow[t]{2}{*}{ Region } & \multicolumn{12}{|c|}{ Month } \\
\hline & $\mathrm{J}$ & $\mathrm{F}$ & $\mathrm{M}$ & A & M & $\mathrm{J}$ & $\mathrm{J}$ & A & $S$ & $\mathrm{O}$ & $\mathrm{N}$ & $\mathrm{D}$ \\
\hline SCA & $\begin{array}{c}-0.0006 \pm 0.0019 \\
(-2 \pm 7)\end{array}$ & $\begin{array}{c}0.0016 \pm 0.0003 \\
(4 \pm 1)\end{array}$ & $\begin{array}{c}0.014 \pm 0.003 \\
(22 \pm 4)\end{array}$ & $\begin{array}{l}0.033 \pm 0.004 \\
(35 \pm 4)\end{array}$ & $\begin{array}{c}0.02 \pm 0.01 \\
(21 \pm 12)\end{array}$ & $\begin{array}{c}0.005 \pm 0.007 \\
(7 \pm 11)\end{array}$ & $\begin{array}{l}0.012 \pm 0.008 \\
(17 \pm 12)\end{array}$ & $\begin{array}{c}0.024 \pm 0.002 \\
(29 \pm 2)\end{array}$ & $\begin{array}{c}0.0163 \pm 0.0002 \\
(25.8 \pm 0.2)\end{array}$ & $\begin{array}{l}0.003 \pm 0.008 \\
(10 \pm 23)\end{array}$ & $\begin{array}{l}0.001 \pm 0.001 \\
\quad(5 \pm 5)\end{array}$ & $\begin{array}{c}0.0005 \pm 0.0004 \\
(2 \pm 1)\end{array}$ \\
\hline WEU & $\begin{array}{c}-0.001 \pm 0.003 \\
(-3 \pm 7)\end{array}$ & $\begin{array}{l}0.002 \pm 0.002 \\
\quad(4 \pm 3)\end{array}$ & $\begin{array}{l}0.002 \pm 0.002 \\
(18 \pm 16)\end{array}$ & $\begin{array}{l}0.014 \pm 0.006 \\
(14 \pm 6)\end{array}$ & $\begin{array}{c}0.001 \pm 0.003 \\
\quad(1 \pm 3)\end{array}$ & $\begin{array}{l}0.001 \pm 0.002 \\
\quad(1 \pm 2)\end{array}$ & $\begin{array}{l}0.002 \pm 0.007 \\
(3 \pm 7)\end{array}$ & $\begin{array}{c}0.001 \pm 0.009 \\
(1 \pm 10)\end{array}$ & $\begin{array}{c}0.006 \pm 0.001 \\
(8 \pm 1)\end{array}$ & $\begin{array}{c}0.0043 \pm 0.0003 \\
(7 \pm 1)\end{array}$ & $\begin{array}{c}0.0013 \pm 0.0005 \\
(3 \pm 1)\end{array}$ & $\begin{array}{c}-0.0003 \pm 0.0010 \\
(-1 \pm 2)\end{array}$ \\
\hline CEU & $\begin{array}{c}-0.003 \pm 0.001 \\
(1 \pm 2)\end{array}$ & $\begin{array}{c}0.0018 \pm 0.0006 \\
(3 \pm 1)\end{array}$ & $\begin{array}{c}0.021 \pm 0.009 \\
(21 \pm 9)\end{array}$ & $\begin{array}{l}0.035 \pm 0.006 \\
\quad(27 \pm 5)\end{array}$ & $\begin{array}{c}0.009 \pm 0.001 \\
(8 \pm 1)\end{array}$ & $\begin{array}{c}0.004 \pm 0.006 \\
\quad(3 \pm 5)\end{array}$ & $\begin{array}{l}0.022 \pm 0.006 \\
\quad(18 \pm 5)\end{array}$ & $\begin{array}{l}0.032 \pm 0.004 \\
\quad(25 \pm 3)\end{array}$ & $\begin{array}{c}0.0194 \pm 0.0005 \\
(21 \pm 1)\end{array}$ & $\begin{array}{c}0.006 \pm 0.006 \\
(11 \pm 10)\end{array}$ & $\begin{array}{c}0.0022 \pm 0.0004 \\
(5 \pm 1)\end{array}$ & $\begin{array}{c}-0.001 \pm 0.002 \\
(-2 \pm 7)\end{array}$ \\
\hline EEU & $\begin{array}{c}0.001 \pm 0.002 \\
(0 \pm 3)\end{array}$ & $\begin{array}{c}0.002 \pm 0.002 \\
\quad(4 \pm 3)\end{array}$ & $\begin{array}{c}0.013 \pm 0.006 \\
(16 \pm 7)\end{array}$ & $\begin{array}{c}0.04 \pm 0.01 \\
(30 \pm 10)\end{array}$ & $\begin{array}{c}0.016 \pm 0.003 \\
\quad(14 \pm 2)\end{array}$ & $\begin{array}{c}0.004 \pm 0.006 \\
(4 \pm 6)\end{array}$ & $\begin{array}{c}0.032 \pm 0.006 \\
(24 \pm 4)\end{array}$ & $\begin{array}{c}0.035 \pm 0.005 \\
(28 \pm 4)\end{array}$ & $\begin{array}{c}0.024 \pm 0.002 \\
(25 \pm 3)\end{array}$ & $\begin{array}{c}0.007 \pm 0.007 \\
(12 \pm 11)\end{array}$ & $\begin{array}{l}0.002 \pm 0.001 \\
\quad(4 \pm 3)\end{array}$ & $\begin{array}{c}0.000 \pm 0.001 \\
(0 \pm 3)\end{array}$ \\
\hline WMD & $\begin{array}{c}-0.0002 \pm 0.0037 \\
(0 \pm 8)\end{array}$ & $\begin{array}{c}0.0034 \pm 0.0007 \\
(6 \pm 1)\end{array}$ & $\begin{array}{c}0.007 \pm 0.002 \\
(10 \pm 3)\end{array}$ & $\begin{array}{c}0.008 \pm 0.008 \\
(10 \pm 10)\end{array}$ & $\begin{array}{c}0.003 \pm 0.006 \\
(4 \pm 7)\end{array}$ & $\begin{array}{c}0.013 \pm 0.007 \\
(13 \pm 7)\end{array}$ & $\begin{array}{c}0.018 \pm 0.004 \\
(19 \pm 4)\end{array}$ & $\begin{array}{c}0.025 \pm 0.003 \\
(25 \pm 3)\end{array}$ & $\begin{array}{c}0.0164 \pm 0.0005 \\
(21 \pm 1)\end{array}$ & $\begin{array}{c}0.0111 \pm 0.0004 \\
(18 \pm 1)\end{array}$ & $\begin{array}{c}0.002 \pm 0.001 \\
(5 \pm 3)\end{array}$ & $\begin{array}{c}0.0002 \pm 0.0015 \\
\quad(1 \pm 4)\end{array}$ \\
\hline CMD & $\begin{array}{c}0.001 \pm 0.003 \\
(2 \pm 5)\end{array}$ & $\begin{array}{l}0.003 \pm 0.001 \\
\quad(4 \pm 2)\end{array}$ & $\begin{array}{c}0.018 \pm 0.003 \\
\quad(19 \pm 3)\end{array}$ & $\begin{array}{l}0.027 \pm 0.006 \\
\quad(22 \pm 5)\end{array}$ & $\begin{array}{c}0.006 \pm 0.009 \\
\quad(5 \pm 8)\end{array}$ & $\begin{array}{c}0.015 \pm 0.006 \\
\quad(12 \pm 4)\end{array}$ & $\begin{array}{l}0.031 \pm 0.005 \\
\quad(23 \pm 4)\end{array}$ & $\begin{array}{c}0.035 \pm 0.003 \\
\quad(26 \pm 2)\end{array}$ & $\begin{array}{c}0.021 \pm 0.004 \\
\quad(19 \pm 4)\end{array}$ & $\begin{array}{c}0.009 \pm 0.008 \\
(11 \pm 10)\end{array}$ & $\begin{array}{l}0.003 \pm 0.001 \\
\quad(4 \pm 2)\end{array}$ & $\begin{array}{c}-0.0004 \pm 0.0028 \\
(-1 \pm 5)\end{array}$ \\
\hline TUR & $\begin{array}{c}-0.001 \pm 0.004 \\
(0 \pm 7)\end{array}$ & $\begin{array}{c}0.0046 \pm 0.0002 \\
(5.5 \pm 0.2)\end{array}$ & $\begin{array}{c}0.014 \pm 0.008 \\
(14 \pm 9)\end{array}$ & $\begin{array}{l}0.021 \pm 0.006 \\
\quad(18 \pm 5)\end{array}$ & $\begin{array}{c}0.01 \pm 0.01 \\
(6 \pm 10)\end{array}$ & $\begin{array}{c}0.017 \pm 0.008 \\
(14 \pm 7)\end{array}$ & $\begin{array}{c}0.036 \pm 0.002 \\
(27 \pm 1)\end{array}$ & $\begin{array}{l}0.044 \pm 0.005 \\
\quad(34 \pm 4)\end{array}$ & $\begin{array}{c}0.029 \pm 0.001 \\
(29 \pm 1)\end{array}$ & $\begin{array}{l}0.016 \pm 0.004 \\
(21 \pm 5)\end{array}$ & $\begin{array}{l}0.004 \pm 0.001 \\
(6 \pm 2)\end{array}$ & $\begin{array}{c}-0.0004 \pm 0.0030 \\
(0 \pm 5)\end{array}$ \\
\hline
\end{tabular}

Med) while, as expected, the most impacted are Eastern and Central Europe as well as Scandinavia.

Major uncertainties in Table 2 estimates (i.e., maximum standard deviations related to maximum difference between the corresponding FFAOT $_{\mathrm{WF}, 1}$ and FFAOT $_{\mathrm{WF}, 2}$ values) are found for the months of May and/or June. This is likely because in May or June, depending on the region, the FFAOT $_{\mathrm{WF}, 1}$ contributions have been necessarily forced to be zero by the sinusoidal fit used, whereas a minimum but not null contribution (as the one derived from the FWTD, i.e., FFAOT $_{W F, 2}$ ), is probably much more realistic.

It is also worth commenting on the good agreement among the CF values obtained for the different regions (Table 1), a result giving robustness to the FWTD-to-FFAOT conversion approach adopted. The only exception is found for the Scandinavia value (more than twice the others CFs), also associated to a rather large variability. The higher CF derived for Scandinavia to match the observed FFAOT values suggests that the FWTD computations in this region are probably underestimated. We speculate this is likely due to an additional contribution of fires from regions east of $70^{\circ} \mathrm{E}$, which are not accounted for in our study (see Sect. 2.3). In fact, similarly to what occurs in the Arctic (Stohl, 2007), Siberian/Asian fires might still have a significant impact at the European northernmost latitudes, particularly in spring, when temperatures are still low and quasi-isentropic transport of cold air from such regions is a potential pathway into the lower troposphere. These fires are conversely expected to have minor impacts over most of continental and Mediterranean Europe.

\subsection{On the possible contribution from intercontinental transport}

One question that may arise is whether, and to which extent, the FFAOT pattern observed over Europe is also influenced by intercontinental transport of pollution from other areas. In particular, given the general westerly circulation of the midlatitude Northern hemisphere, transport from North America might provide a not negligible contribution to the European AOT (and mainly FFAOT) levels (e.g., Penkett et al., 2003; Huntrieser et al., 2005; Li et al., 2005), which, in principle, could bias our results. To check this possibility we further selected nine "control regions" over the Atlantic Ocean, off the European coasts (labelled A to I in Fig. 1), and applied our analysis also to these. Boundaries of the control regions were chosen in order to investigate both latitudinal and longitudinal AOT gradients from Europe as a function of the prevailing atmospheric circulation.

Yearly cycles of the MISR FFAOT in the nine control regions are reported in Fig. 7 (thick gray lines). As expected, FWTD values computed for these regions are negligible (at least two order of magnitude lower than those derived in the seven European target regions and shown in Fig. 4) and are therefore omitted in the plot.

Since aerosol production and westerly transport from North America towards Europe is most effective in the period April-July (e.g., Auvray and Bey, 2005), the sinusoidal curves (thin black lines in Fig. 7) in the control regions have been obtained by only fitting the January-to-March and August-to-December FFAOT values. In addition, to better interpret Fig. 7 results, we show (1) in Fig. 8 two examples of the average FFAOT field in the investigated area (monthly mean of April and July in the period 2002-2007, Fig. 8a and $8 \mathrm{~b}$ respectively) and (2) in Fig. 9 the corresponding mean wind fields at $925 \mathrm{mb}$.

Main outcomes from data in Fig. 7 are the following: in the three northernmost Atlantic regions (A, B, C) the FFAOT yearly cycle closely follows a sinusoidal behaviour, while in the southernmost regions $(\mathrm{G}, \mathrm{H}, \mathrm{I})$ a deviation from such regular behaviour is clearly visible from April to July. Figures 8 and 9 reveal this is due to the aerosol production and transport from Northern-Central America. Also, a minor Westto-East gradient (Fig. $7 \mathrm{~g}$ to $\mathrm{i}$ ) is observed suggesting that, in this period of the year, the Western Mediterranean target region might still receive a contribution from such transport (thus contributing to the FFAOT values of Fig. 4e). If this is 

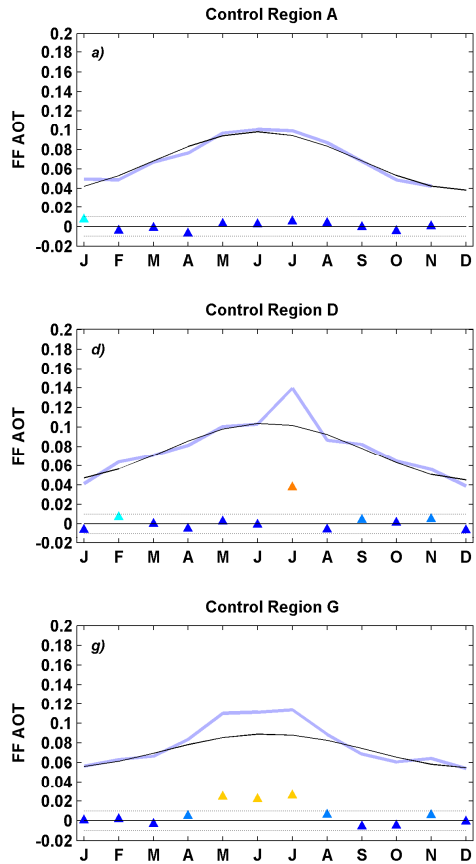
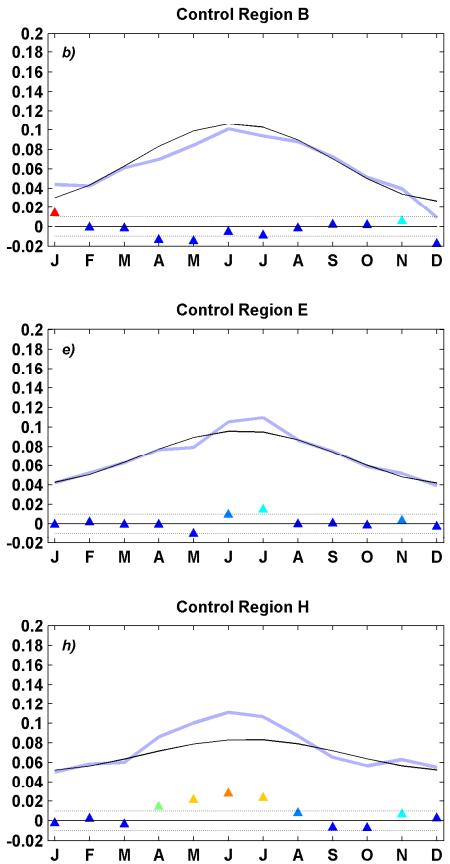
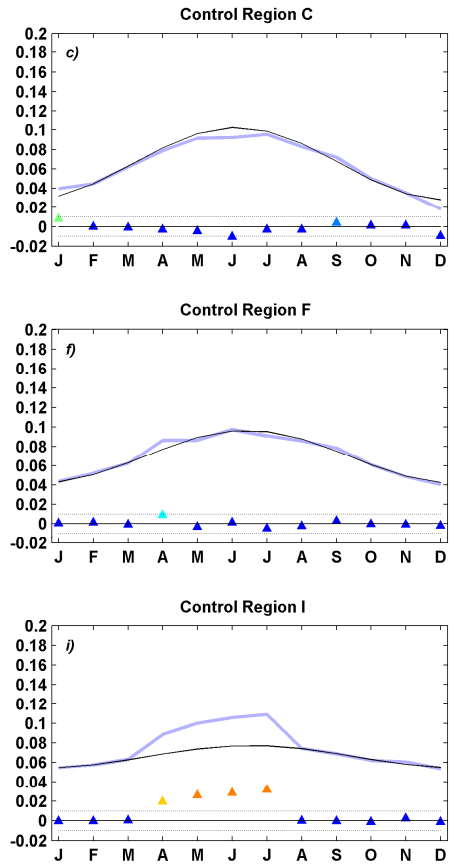

Fig. 7. Each panel (a to i, referring to one of the nine "control regions" A to I of Fig. 1) shows the monthly mean FFAOT as measured

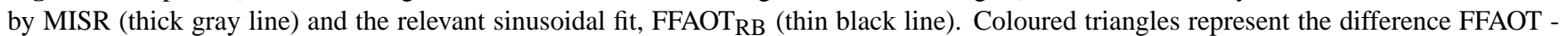
FFAOT $_{\mathrm{RB}}$ (the colour code indicating the (FFAOT - FFAOT $_{\mathrm{RB}}$ )/FFAOT percentage, as in Fig. 6).

the case, the April-to-July wildfires contributions estimated for the Western Mediterranean (Fig. 6 and Table 2) might be overestimated. Similarly, some deviation from the sinusoidal behaviour is found in control regions D (July) and E (JuneJuly). The FFAOT field (Fig. 8b) indicates this deviation to be still due to aerosols advected from North America, which, favoured by the high wind speed (Fig. 9b), reach up to those latitudes (Li et al., 2002). In this case a West-to-East gradient is observed (Fig. 7d to f) and the effect is completely lost off the Irish coasts (Fig. 7f). Thus no impact from such transport is expected in the Western Europe region considered in this study. This is also consistent with black carbon observations at Mace Head (Ireland), where air masses from the Atlantic "clean" sector are found to be recently influenced by human activity only $5 \%$ of the times (Cooke et al., 1997). Rather, the AOT (and FFAOT) peak observed over this region in March (Fig. 4b) is due to an increase in the aerosol load over the ocean, and namely over the English Channel and the Bay of Biscay (not shown here). The reason for such an aerosol increase in this period of the year is unclear, but this allows excluding it is due to fires. Due to the frequent algal blooms in this period of the year (e.g., Lampert et al., 2002; Gohin et al., 2003), we speculate such increase might either be a real aerosol signal (e.g., marine organic aerosol produced from phytoplankton (O’Dowd et al., 2004)) or the result of the "ocean colour" misinterpreted as aerosols by the signal inversion scheme. Again, for this month/region the

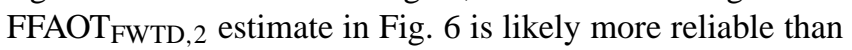
the corresponding FFAOT $_{\mathrm{FWTD}}, 1$ one.

Overall, the analysis over the control Atlantic regions points to a negligible contamination by westerly particle transport towards Europe on our results, except for the Western Mediterranean region.

\section{Discussion and conclusions}

Wildfires represent an important global source of trace gases and aerosols and may represent an important climatic variable as well as a threat for air quality and the environment in general.

In the European continent agricultural burning, used to remove crop residues for new planting or clear weeds and brush for grazing, is a common practice, in particular in Eastern Europe and European Russia, where the largest fraction of wildland fires occurs. Also, a large number of forest fires is registered in Europe in summer.

A clear identification of the atmospheric effects of these fires far from the source region is not straightforward, especially in terms of advected particulate matter. In fact, detection of aged smoke is hampered by the important modifications fires-originated particles undergo during the transport, 

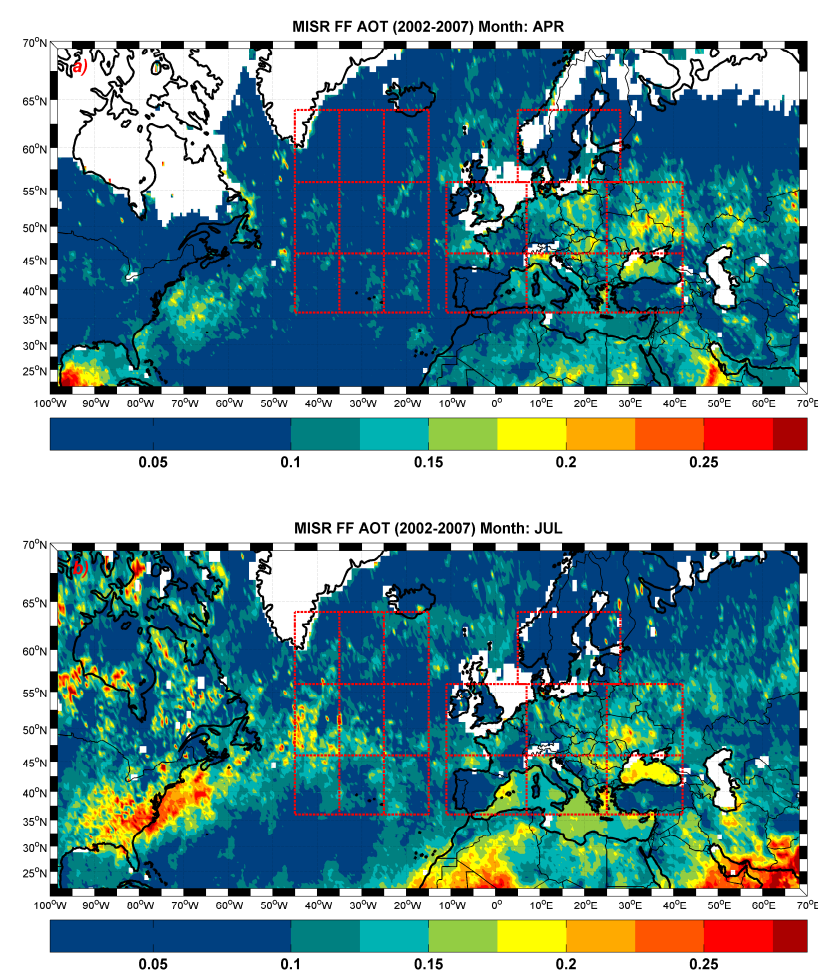

Fig. 8. Monthly mean (years 2002-2007) Fine Fraction Aerosol Optical Thickness (FFAOT) as measured by MISR in April (a) and July (b). The seven target European regions and the nine Atlantic control regions are also indicated (red dashed lines). Blank areas indicate missing data.

and, particularly in densely populated regions such as Europe, by the chemical transformations and mixing with other particles of both anthropogenic and natural origin (e.g. Péré et al., 2009). Numerous studies available in literature reported on the impacts of episodic biomass burning events in Europe, but, to our knowledge, these efforts have not yet led to a comprehensive evaluation of the role these fires play on the aerosol load at the continental scale.

In this study we used long term (2002-2007) remote sensing observation of aerosol optical thickness (AOT) and fires combined with atmospheric transport simulations to start filling this gap. We employed AOT and fires datasets from the NASA Terra MISR and MODIS sensors respectively, while atmospheric transport has been simulated with the NOAA HYSPLIT Lagrangian integrated trajectory model. Some simplifications have been made in this preliminary assessment, the effect of which need to be further investigated in future work, as well as the use of other available AOT and fires/burned area datasets, to reach more definitive conclusions. For example, the $2.5^{\circ}$ horizontal resolution of starting points used in this study could be refined having at disposal higher computational resources. However, as the modelled atmospheric transport is not expected to be much affected by a)

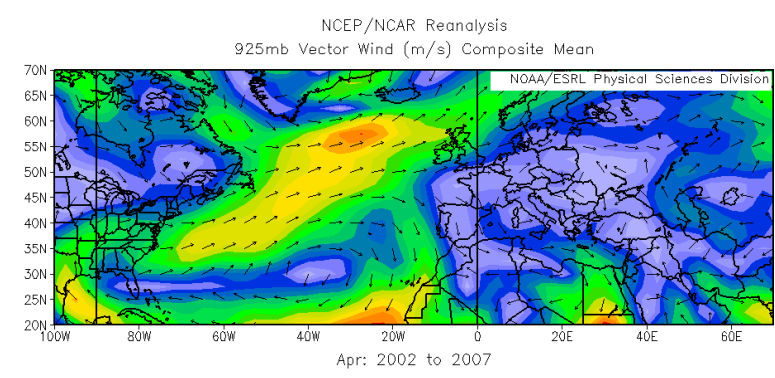

b)

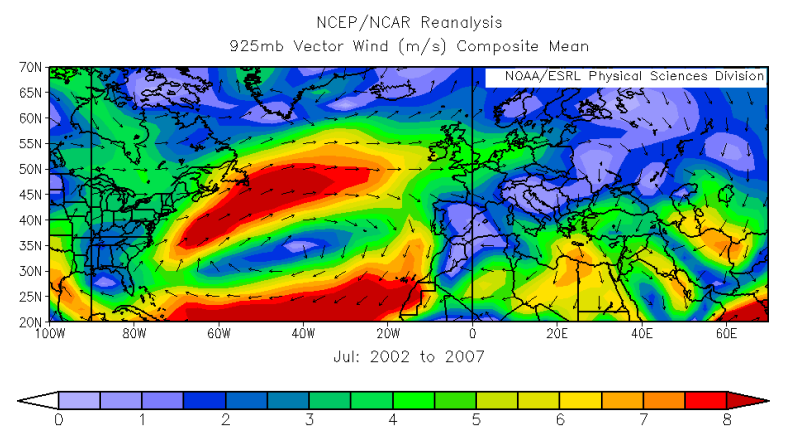

Fig. 9. Monthly mean (2002-2007) wind field at $925 \mathrm{mb}$ in April (a) and July (b) as derived from NCEP/NCAR reanalysis.

a finer resolution (it is basically driven by synoptic winds), the main effect of such improvement will likely convert into a more careful evaluation of small fires. Also, due to the use of data from a single, polar satellite we neglected here possible effects of fire diurnal cycles. Nonetheless, this approximation is expected to have a minor impact on our results due to the weak diurnal cycle of fires generally observed in the Eurasia region with respect to other areas of the world (Giglio et al., 2006).

Overall, notwithstanding the various simplifications adopted, our study clearly indicates that, over Europe, wildfires contribute forming a continent-wide smoky haze. As observed in other areas of the world (e.g., McMeeking et al., 2006, Li et al., 2010), this is likely not only caused by the direct increase in the regional aerosol load, but also via modifications of the chemical/physical properties of existing aerosol particles in downwind areas.

Our preliminary estimates indicate that in spring and summer, 10 to $30 \%$ of the fine fraction aerosol optical thickness (FFAOT) in Europe is related to wildfires emissions. Possible contamination of these results from intercontinental transport of pollution from North America is shown to be almost negligible and limited to the Western Mediterranean region.

In April, when agricultural fires maximize and atmospheric circulation is most favourable (remember for example the dramatic spread to Central and Northern Europe of the Chernobyl nuclear plume, in April 1986, e.g. Albercel 
et al., 1988), an evident impact of wildfires is visible over Europe, with maximum contribution to the FFAOT of 20$35 \%$ in Central and Eastern Europe, Scandinavia and Central Mediterranean. In August the wildfires contribution to the FFAOT overcomes $25 \%$ all over the continent, with the exception of Western Europe. With respect to the summer fires, partly associated to the burning of forest-type vegetation, our analysis suggests a still underrated impact of spring agricultural fires (particularly active in Eastern Europe and ex-USSR countries as Ukraine, Kazakhstan and Russian Federation) on the continental AOT. These events should thus represent a clear target for mitigation (FAO, 2009).

This finding should be also considered in view of the high potential of Eastern Europe, and particularly Ukraine, in terms of land availability for growing bio-energy feedstocks foreseen for the next 30-years (Fisher et al., 2010), thus embodying a source region of renewable energy and greenhouse gas emission reductions. In fact, the European Commission's recent report on the sustainability of biomass (EC, 2010) concluded that where forest or agricultural residues are used for heat and power applications, and as long as the biomass production does not cause any land-use change, the greenhouse gas savings of European feedstocks are generally above $80 \%$ compared to the fossil fuel alternative.

Given the proven fingerprints of wildfires in the atmospheric column, an aspect that would also merit further investigation is their impact onto the lowest atmospheric levels, i.e., on the European air quality. In fact, some evidences of an important impact at the ground are available in literature. For example, the effect of agricultural burning was well detectable in long-term aerosol measurement performed at the ground in Crete, Greece (e.g., Sciare et al., 2008). A 20-to-200\% increase in $\mathrm{PM}_{2.5}$ ground concentrations was estimated by Hodzic et al. (2007) over a large part of Europe during the intense fire season that occurred in summer 2003, particularly in Portugal. Unusually high levels of $\mathrm{PM}_{2.5}$ and PM10 due to long-range transport of smoke from widespread agricultural burning and forest fires in western Russia were observed in the UK in September 2002 and May 2006 (Witham and Manning, 2007) and in Finland in AprilMay 2006 (Saarikoski et al., 2007). More recently, a not negligible contribution to PM values at European high altitude background sites has been attributed to long range transport of biomass burning from the Baltic countries, Byelorussia, Western Russia and Kazakhstan (Salvador et al., 2010). However, as for the AOT observations, these studies are still fragmented in space and time so that a comprehensive assessment of these effects at the European scale is also missing. A rough estimate from our results would suggest a spring and summer contribution of wildfires to monthly-mean PM levels at the ground of about $10 \mu \mathrm{g} \mathrm{m}^{-3}$. This was estimated considering a mean wildfires FFAOT of 0.04 (e.g. Fig. 6), uniformly distributed within a $1000 \mathrm{~m}$-thick atmospheric column, assuming a typical mass-to-extinction coefficient of $4.0 \mathrm{~m}^{2} \mathrm{~g}^{-1}$ (Reid et al., 2005b). Considering the $50 \mu \mathrm{g} \mathrm{m}^{-3}$ daily threshold (not to be exceeded more than 35 times per calendar year) established by the current European legislation (Directive 2008/50/EC), this contribution would definitely be significant for air quality evaluation purposes.

\section{Supplementary material related to this article is available online at: http://www.atmos-chem-phys.net/11/10487/2011/ acp-11-10487-2011-supplement.pdf.}

Acknowledgements. We gratefully acknowledge the MODIS and MISR mission scientists and associated NASA personnel for the production of the data used in this research effort and the NOAA Air Resources Laboratory (ARL) for the provision of the HYSPLIT transport and dispersion model used in this publication. The MISR data were obtained from the NASA Langley Research Center Atmospheric Sciences Data Center. MODIS fires count data used in this study were obtained from the NEO web portal as part of the NASA EOS Project Science Office. MODIS FRP data were produced with the Giovanni online data system (NASA GES DISC) under the NASA Northern Eurasia Earth Science Partnership Initiative - NEESPI. The NASA NEESPI Data and Services Center project is supported by NASA HQ through ROSES 2005 NNH05ZDA001NACCESS.

We also thank the three anonymous reviewers for their constructive comments and useful suggestions.

Edited by: A. Laaksonen

\section{References}

Acker, J. G. and Leptoukh, G.: Online Analysis Enhances Use of NASA Earth Science Data, EOS T. Am. Geophys. Un., 88, 1417, 2007.

Aculinin, A., Holben, B., Smirnov, A., and Eck, T.: Measurements of aerosol optical properties at the Kishinev site, Moldova, Moldavian Journal of the Physical Sciences, 3, 214-225, 2004.

Ahmed, A. A., Mohamed, A., Ali, A. E., Barakat, A., Abd El-Hady, M., and El-Hussein, A.: Seasonal variations of aerosol residence time in the lower atmospheric boundary layer, J. Environ. Radioactivity, 77, 275-283, 2004.

Albercel, A., Martini, D., Strauss, B. and Gross, J.-M.: The Chernobyl accident: modelling of dispersion over Europe of the radioactive plume and comparison with air activity measurements, Atmos. Environ., 22, 2431-2444, 1988.

Alves, C., Vicente, A., Nunes, T., Goncalves, C., Fernandes A., Mirante, F., Tarelho, L., Sanchez de la Campa, A., Querol, X., Caseiro, A., Monteiro, C., and Evtyugi, M.: Summer 2009 wildfires in Portugal: Emission of trace gases and aerosol composition, Atmos. Environ., 45, 641-649, 2011.

Amiridis, V., Balis, D. S., Giannakaki, E., Stohl, A., Kazadzis, S., Koukouli, M. E., and Zanis, P.: Optical characteristics of biomass burning aerosols over Southeastern Europe determined from UVRaman lidar measurements, Atmos. Chem. Phys., 9, 2431-2440, doi:10.5194/acp-9-2431-2009, 2009. 
Andreae, M. O. and Merlet, P.: Emission of trace gases and aerosols from biomass burning, Global Biogeochem. Cy. , 15, 955-966, 2001.

Arola, A., Lindfors, A., Natunen, A., and Lehtinen, K. E. J.: A case study on biomass burning aerosols: effects on aerosol optical properties and surface radiation levels, Atmos. Chem. Phys., 7, 4257-4266, doi:10.5194/acp-7-4257-2007, 2007.

Auvray, M. and Bey, I.: Long-range transport to Europe: Seasonal variations and implications for the European ozone budget, J. Geophys. Res., 110, D11303, doi:10.1029/2004JD005503, 2005.

Balis, D. S., Amiridis. V., Zerefos, C., Gerasopoulos, E., Andreae, M., Zanis, P., Kazantzidis, A., Kazadzis, S., and Papayannis, A.: Raman lidar and sunphotometric measurements of aerosol, optical properties over Thessaloniki, Greece during a biomass burning episode, Atmos. Environ., 37, 4529-4538, 2003.

Barnaba, F. and Gobbi, G. P.: Aerosol seasonal variability over the Mediterranean region and relative impact of maritime, continental and Saharan dust particles over the basin from MODIS data in the year 2001, Atmos. Chem. Phys., 4, 2367-2391, doi:10.5194/acp-4-2367-2004, 2004.

Chubarova, N. Y.: Seasonal distribution of aerosol properties over Europe and their impact on UV irradiance, Atmos. Meas. Tech., 2, 593-608, doi:10.5194/amt-2-593-2009, 2009.

Cooke, W. F., Jennings S. G., and Spain T. G.: Black carbon measurements at Mace Head, 1989-1996, J. Geophys. Res., 102, 25339-25346, 1997.

d'Almeida, G. A., Koepke, P., and Shettle, E. P.: Atmospheric aerosols: global climatology and radiative characteristics, A. Deepak Pub. Hampton, Va., USA, 561 pp., 1991.

Damoah, R., Spichtinger, N., Forster, C., James, P., Mattis, I., Wandinger, U., Beirle, S., Wagner, T., and Stohl, A.: Around the world in 17 days - hemispheric-scale transport of forest fire smoke from Russia in May 2003, Atmos. Chem. Phys., 4, 13111321, doi:10.5194/acp-4-1311-2004, 2004.

Diner, D. J., Beckert, J. C., Reilly, T. H., Bruegge, C. J., Conel, J. E., Kahn, R., Martonchik, J. V., Ackerman, T. P., Davies, R., Gerstl, S. A. W., Gordon, H.R., Müller, J.-P., Myneni, R., Sellers, R. J., Pinty, B. , and Verstraete, M. M.: Multi-angle Imaging Spectro Radiometer (MISR) description and experiment overview, IEEE Trans. Geosci. Rem. Sens., 36, 1072-1087, 1998.

Draxler, R. R. and Hess, G. D.: An overview of the HYSPLIT_4 modeling system of trajectories, dispersion, and deposition, Aust. Meteor. Mag., 47, 295-308, 1998.

EC-European Commission: Report from the Commission to the Council and the European Parliament on sustainability requirements for the use of solid and gaseous biomass sources in electricity, heating and cooling, $\operatorname{COM}(2010) 11,2010$.

Edwards, D. P., Emmons, L. K., Hauglustaine, D. A., Chu, D. A., Gille, J. C., Kaufman, Y. J., Petron, G., Yurganov, L. N., Giglio, L., Deeter, M. N., Yudin, V., Ziskin, D. C., Warner, J., Lamarque, J.-F., Francis, G. L., Ho, S. P., Mao, D., Chen, J., Grechko, E. I., and Drummond, J. R.: Observations of carbon monoxide and aerosols from the Terra satellite: Northern Hemisphere variability, J. Geophys. Res., 109, D24202, doi:10.1029/2004JD004727, 2004.

FAO (Food and Agriculture Organization): Forest fires and the law - A guide for national drafters based on the Fire Management Voluntary Guidelines, FAO LEGISLATIVE STUDY 99, ISBN 978-92-5-106151-0, 175 pp., 2009.
Fischer, G., Prieler, S., van Velthuizen, H., Berndes, G., Faaij, A., Londo, M., and de Wit, M.: Biofuel production potentials in Europe: Sustainable use of cultivated land and pastures, Part II: Land use scenarios, Biomass Bioenerg., 34, 173-187, 2010.

Formenti, P., Boucher, O., Reiner, T., Sprung, D., Andreae, M. O., Wendisch, M., Wex, H., Kindred, D., Tzortziou, M., Vasaras, A., and Zerefos, C.: STAAARTE-MED 1998 summer airborne measurements over the Aegean Sea, 2, Aerosol scattering and absorption, and radiative calculations, J. Geophys. Res., 107, 4451, doi:10.1029/2001JD001536, 2002.

Generoso, S., Bey, I., Attié, J.-L., and Bréon, F.-M.: A satelliteand model-based assessment of the 2003 Russian fires: Impact on the Arctic region, J. Geophys. Res., 112, D15302, doi:10.1029/2006JD008344, 2007.

Giglio, L., Descloitres, J., Justice, C. O., and Kaufman, Y.: An enhanced contextual fire detection algorithm for MODIS, Remote Sens. Environ., 87, 273-282, 2003.

Giglio, L., Csiszar, I., and Justice, C. O.: Global distribution and seasonality of active fires as observed with the Terra and Aqua Moderate Resolution Imaging Spectroradiometer (MODIS) sensors, J. Geophys. Res., 111, G02016, doi:10.1029/2005JG000142, 2006.

Gohin, F., Lampert, L., Guillaud, J.-F., Herbland, A., and. Nézan, E: Satellite and in situ observations of a late winter phytoplankton bloom, in the northern Bay of Biscay, Cont. Shelf. Res., 23, 1117-1141, 2003.

Hays, M. D., Fine, P. M., Geron, C. D., Kleeman, M. J., and Gullett, B.K .: Open burning of agricultural biomass: Physical and chemical properties of particle-phase emissions, Atmos. Environ., 39, 6747-6764, 2005.

Hodzic, A., Madronich, S., Bohn, B., Massie, S., Menut, L., and Wiedinmyer, C.: Wildfire particulate matter in Europe during summer 2003: meso-scale modeling of smoke emissions, transport and radiative effects, Atmos. Chem. Phys., 7, 4043-4064, doi:10.5194/acp-7-4043-2007, 2007.

Holben, B. N., Eck, T. F., Slutsker, I., Tanre, D., Buis, J. P., Setzer, A., Vermote, E., Reagan, J. A., Kaufman, Y. J., Nakajima, T., Lavenu, F., Jankowiak, I., and Smirnov, A.: AERONET - A federated instrument network and data archive for aerosol characterization, Rem. Sens. Env., 66, 1-16, 1998.

Huntrieser, H., Heland, J., Schlager, H., Forster, C., Stohl, A., Aufmhoff, H., Arnold, F., Scheel, H. E., Campana, M., Gilge, S., Eixmann, R., and Cooper, O.: Intercontinental air pollution transport from North America to Europe: Experimental evidence from airborne measurements and surface observations, J. Geophys. Res., 110, D01305, doi:10.1029/2004JD005045, 2005.

Janhäll, S., Andreae, M. O., and Pöschl, U.: Biomass burning aerosol emissions from vegetation fires: particle number and mass emission factors and size distributions, Atmos. Chem. Phys., 10, 1427-1439, doi:10.5194/acp-10-1427-2010, 2010.

Justice C., Giglio, L., Boschetti, L., Roy, D., Csiszar, I., Morisette, J., and Kaufman, Y.: Modis Fire Products - Algorithm Technical Background Document (available at: http://modis.gsfc.nasa.gov/ data/atbd/atbd_mod14.pdf, 2006.

Kasischke, E. S. and Penner, J. E.: Improving global estimates of atmospheric emissions from biomass burning, J. Geophys. Res., 109, D14S01, doi:10.1029/2004JD004972, 2004.

Kahn, R. A., Gaitley, B. J., Garay, M. J., Diner, D. J., Eck, T., Smirnov, A., and Holben, B. N.: MISR aerosol product assess- 
ment by comparison with AERONET, J. Geophys. Res., 115, D23209, doi:10.1029/2010JD014601, 2010.

Kaufman, Y. J., Justice, C. O., Flynn, L. P., Kendall, J. D., Prins, E. M., Giglio, L., Ward, D. E., Menzel, W. P., and Setzer, A. W.: Potential global fire monitoring from EOS-MODIS, J. Geophys. Res., 103, 32215-32238, 1998.

Koelemeijer, R. B. A., Homan, C. D., and Matthijsen, J.: Comparison of spatial and temporal variations of aerosol optical thickness and particulate matter over Europe, Atmos. Environ., 40, 53045315, 2006.

Korontzi, S., McCarty, J., Loboda, T., Kumar, S., and Justice, C.: Global distribution of agricultural fires in croplands from 3 years of Moderate Resolution Imaging Spectroradiometer (MODIS) data, Global Biogeochem. Cy., 20, GB2021, doi:10.1029/2005GB002529, 2006.

Lampert, L., Queguiner, B., Labasque, T., Pichon, A., and Lebreton, N.: Spatial variability of phytoplankton composition and biomass on the eastern continental shelf of the Bay of Biscay (north-east Atlantic Ocean). Evidence for a bloom of Emiliania huxleyi (Prymnesiophyceae) in spring 1998, Cont. Shelf Cont. Shelf Res., 22, 1225-1247, 2002.

Langmann, B., Duncan, B., Textor, C., Trentmannd, J., van der Werf, G.: Vegetation fire emissions and their impact on air pollution and climate, Atmos. Environ., 43, 107-116, 2009.

Li, Q., Jacob, D. J., Bey, I., Palmer, P. I., Duncan, B. N., Field, B. D., Martin, R. V., Fiore, A. M., Yantosca, R. M., Parrish, D. D., Simmonds, P. G., and Oltmans, J. S.: Transatlantic transport of pollution and its effects on surface ozone in Europe and North America, J. Geophys. Res., 107, D13, doi:10.1029/2001JD001422, 2002.

Li, Q., Jacob, D. J., Park, R. Wang, Y., Heald, C. L., Hudman, R., Yantosca, R. M., Martin, R. V., and Evans, M.: North American pollution outflow and the trapping of convectively lifted pollution by upper-level anticyclone, J. Geophys. Res., 110, D10301, doi:10.1029/2004JD005039, 2005.

Li, W. J., Shao, L. Y., and Buseck, P. R.: Haze types in Beijing and the influence of agricultural biomass burning, Atmos. Chem. Phys., 10, 8119-8130, doi:10.5194/acp-10-8119-2010, 2010.

Marmer, E., Langmann, B., Fagerli, H., and Vestreng, V.: Direct shortwave radiative forcing of sulfate aerosol over Europe from 1900 to 2000, J. Geophys. Res., 112, D23S17, doi:10.1029/2006JD008037, 2007.

Martonchik, J. V., Kahn, R.A., and Diner, D. J.: Retrieval of Aerosol Properties over Land Using MISR Observations, in: Satellite Aerosol Remote Sensing Over Land, edited by: Kokhanovsky, A. A. and de Leeuw, G., Springer Praxis Books, Berlin, 267-293, doi:0.1007/978-3-540-69397-0_9, 2009.

McMeeking, G. R., Kreidenweis, S. M., Lunden, M., Carrillo, J., Carrico, C. M., Lee, T., Herckes, P., Engling, G., Day, D. E., Hand, J., Brown, N., Malm, W. C., and Collett, J. L.: Smokeimpacted regional haze in California during the summer of 2002, Agr. Forest. Meteorol., 137, 25-42, 2006.

Menut, L. and Bessagnet, B.: Atmospheric composition forecasting in Europe, Ann. Geophys., 28, 61-74, doi:10.5194/angeo-28-612010, 2010.

Mehta, A. V. and Yang, S.: Precipitation climatology over Mediterranean Basin from ten years of TRMM measurements, Adv. Geosci., 17, 87-91, doi:10.5194/adgeo-17-87-2008, 2008.

Mollicone, D., Eva, H. D., and Achard, F.: Human role in Russian wild fires, Nature, 440, 436-437, doi:10.1038/440436a, 2006.

Moulin, C., Lambert, C. E., Dayan, U., Masson, V., Ramonet, M., Bousquet, P., Legrand, M., Balkanski, Y. J., Guelle, W., Marticorena, B., Bergametti, G., and Dulac, F.: Satellite climatology of African dust transport in the Mediterranean atmosphere, J. Geophys. Res., 103, 13137-13144, 1998.

Müller, D., Mattis, I., Wandinger, U., Ansmann, A., Althausen, D., Stohl, A.: Raman lidar observations of aged Siberian and Canadian forest fire smoke in the free troposphere over Germany in 2003: Microphysical particle characterization, J. Geophys. Res., 110, D17201, doi:10.1029/2004JD005756, 2005.

Niemi, J. V., Tervahattu, H., Vehkamäki, H., Martikainen, J., Laakso, L., Kulmala, M., Aarnio, P., Koskentalo, T., Sillanpää, M., and Makkonen, U.: Characterization of aerosol particle episodes in Finland caused by wildfires in Eastern Europe, Atmos. Chem. Phys., 5, 2299-2310, doi:10.5194/acp-5-2299-2005, 2005.

O’Dowd, C., Facchini, M. C., Cavalli, F., Ceburnis, D., Mircea, M., Decesari, S., Fuzzi, S., Yoon, Y. J., and Putaud, J.-P.: Biogenically-driven organic contribution to marine aerosol, $\mathrm{Na}-$ ture, 431, 676-680, 2004.

Pace, G., Meloni, D., and di Sarra, A.: Forest fire aerosol over the Mediterranenan basin during summer 2003, J. Geophys. Res., 110, D21202, doi:10.1029/2005JD005986, 2005.

Papadimas, C. D., Hatzianastassiou, N., Mihalopoulos, N., Querol, X., and Vardavas, I.: Spatial and temporal variability in aerosol properties over the Mediterranean basin based on 6year (2000-2006) MODIS data, J. Geophys. Res., 113, D11205, doi:10.1029/2007JD009189, 2008.

Papayannis, A., Amiridis, V., Mona, L., Tsaknakis, G., Balis, D., Bosenberg, J., Chaikovski, A., De Tomasi, F., Grigorov, I., Mattis, I., Mitev, V., Müller, D., Nickovic, S., Perez, C., Pietruczuk, A., Pisani, G., Ravetta, F., Rizi, V., Sicard, M., Trickl, T., Wiegner, M., Gerding, M., Mamouri, R. E., D’Amico, G., and Pappalardo, G.: Systematic lidar observations of Saharan dust over Europe in the frame of EARLINET (2000-2002), J. Geophys. Res., 113, D10204, doi:10.1029/2007JD009028, 2008.

Papastefanou, C.: Residence time of tropospheric aerosols in association with radioactive nuclides, Appl. Radiat. Isotopes, 64, 93-100, 2006.

Penkett, S. A., Law, K., Plat,t U. and Volz-Thomas, A.: European Export of Particulates and Ozone by Long-Range Transport Overview of Subproject EXPORT-E2, in Towards Cleaner Air for Europe - Science, Tools and Applications - Part 2. Overviews from the Final Reports of the EUROTRAC-2 Subprojects, edited by: Midgley, P. M. and Reuther, M., ISBN 3-8236-1391-X, 99118, Margraf Verlag, Weikersheim, 2003.

Péré, J. C., Mallet, M., Bessagnet, B., and Pont, V.: Evidence of the aerosol core-shell mixing state over Europe during the heat wave of summer 2003 by using CHIMERE simulations and AERONET inversions, Geophys. Res. Lett., 36, L09807, doi:10.1029/2009GL037334, 2009.

Reid, J. S., Koppmann, R., Eck, T. F., and Eleuterio, D. P.: A review of biomass burning emissions part II: intensive physical properties of biomass burning particles, Atmos. Chem. Phys., 5, 799825, doi:10.5194/acp-5-799-2005, 2005a.

Reid, J. S., Eck, T. F., Christopher, S. A., Koppmann, R., Dubovik, O., Eleuterio, D. P., Holben, B. N., Reid, E. A., and Zhang, J.: A review of biomass burning emissions part III: intensive optical 
properties of biomass burning particles, Atmos. Chem. Phys., 5, 827-849, doi:10.5194/acp-5-827-2005, 2005.

Rangarajan, C.: A Study of the Mean Residence Time of the Natural Radioactive Aerosols in the Planetary Boundary Layer, J. Environ. Radioactivity, 15, 193-206, 1992.

Saarikoski, S., Sillanpaa, M., Sofiev, M., Timonen, H., Saarnio, K., Teinila, K., Karppinen, A., Kukkonen, J., and Hillamo, R.: Chemical composition of aerosols during a major biomass burning episode over northern Europe in spring 2006: Experimental and modelling assessments, Atmos. Environ., 41, 3577-3589, 2007.

Saarnio, K., Aurela, M., Timonen, H., Saarikoski, S., Teinilä, K., Mäkelä, T., Sofiev, M., Koskinen, J., Aalto, P. P., Kulmala, M., Kukkonen, J., and Hillamo, R.: Chemical composition of fine particles in fresh smoke plumes from boreal wild-land fires in Europe, Sci. Total Environ., 408, 2527-2542, 2010.

Salvador, P., Artíñano, B., Pio, C., Afonso, J., Legrand, M., Puxbaum, H., and Hammer, S.: Evaluation of aerosol sources at European high altitude background sites with trajectory statistical methods, Atmos. Environ., 44, 2316-2329, 2010.

Sicard, M., Rocadenbosch, F., Reba, M. N. M., Comerón, A., Tomás, S., García-Vízcaino, D., Batet, O., Barrios, R., Kumar, D., and Baldasano, J. M.: Seasonal variability of aerosol optical properties observed by means of a Raman lidar at an EARLINET site over Northeastern Spain, Atmos. Chem. Phys., 11, 175-190, doi:10.5194/acp-11-175-2011, 2011.

Sciare, J., Oikonomou, K., Favez, O., Liakakou, E., Markaki, Z., Cachier, H., and Mihalopoulos, N.: Long-term measurements of carbonaceous aerosols in the Eastern Mediterranean: evidence of long-range transport of biomass burning, Atmos. Chem. Phys., 8, 5551-5563, doi:10.5194/acp-8-5551-2008, 2008.
Stohl, A., Berg, T., Burkhart, J. F., Fj?raa, A. M., Forster, C., Herber, A., Hov, Ø., Lunder, C., McMillan, W. W., Oltmans, S., Shiobara, M., Simpson, D., Solberg, S., Stebel, K., Ström, J., Tørseth, K., Treffeisen, R., Virkkunen, K., and Yttri, K. E.: Arctic smoke record high air pollution levels in the European Arctic due to agricultural fires in Eastern Europe in spring 2006, Atmos. Chem. Phys., 7, 511-534, doi:10.5194/acp-7-511-2007, 2007.

Tegen, I., Koch, D., Lacis, A. L., and Sato, M.: Trends in tropospheric aerosol loads and corresponding impact on direct radiative forcing between 1950 and 1990: A model study, J. Geophys. Res., 105, 26,971-26,989, 2000.

Warneke, C., Froyd, K. D., Brioude, J., Bahreini, R., Brock, C. A., Cozic, J., de Gouw, J. A., Fahey, D. W., Ferrare, R., Holloway, J. S., Middlebrook, A. M., Miller, L., Montzka, S., Schwarz, J. P., Sodemann, H., Spackman, J. R., and Stohl, A.: An important contribution to springtime Arctic aerosol from biomass burning in Russia, Geophys. Res. Lett., 37, L01801, doi:10.1029/2009GL041816, 2010.

Wiedinmyer, C., B. Quayle, C. Geron, A. Belote, D. McKenzie, X. Zhang, S. O’Neill, K. Klos, Wynne: Estimating emissions from fires in North America for air quality modelling, Atmos. Environ., 40, 3419-3432, 2006.

Witham, C. and Manning, A: Impacts of Russian biomass burning on UK air quality, Atmos. Environ., 41, 8075-8090, 2007.

Wooster, M. J., Roberts, G., and Perry, G. L. W.: Retrieval of biomass combustion rates and totals from fire radiative power observations: FRP derivation and calibration relationships between biomass consumption and fire radiative energy release, J. Geophys. Res., 110, D24311, doi:10.1029/2005JD006318, 2005

Yu, H., Dickinson, R. E., Chin, M., Kaufman, Y. J., Holben, B. N. Geogdzhayev, I. V., and Mishchenko, M. I.: Annual cycle of global distributions of aerosol optical depth from integration of MODIS retrievals and GOCART model simulations, J. Geophys. Res., 108, 4128, doi:10.1029/2002JD002717, 2003. 